Assimilação do valor meio ambiente pela sociedade brasileira

Dissertação de mestrado apresentada à Escola de Engenharia de São Carlos, para obtenção do título de Mestre.

Área de Concentração: Ciências da Engenharia Ambiental

Orientador: Prof. Dr. Marcelo Pereira de Souza

São Carlos 
AUTORIZO A REPRODUÇÃO E DIVULGAÇÃO TOTAL OU PARCIAL DESTE TRABALHO, POR QUALQUER MEIO CONVENCIONAL OU ELETRÔNICO PARA FINS DE ESTUDO E PESQUISA, DESDE QUE CITADA A FONTE.

Ficha catalográfica preparada pela Seção de Tratamento da Informação do Serviço de Biblioteca - EESC/USP

F83a

Ferreira Neto, Themístocles Barbosa Assimilação do valor meio ambiente pela sociedade Brasileira / Themístocles Barbosa Ferreira Neto ;

Orientador Marcelo Pereira de Souza. - São Carlos, 2007.

Dissertação (Mestrado- Programa de Pós-Graduação e Área de Concentração em ciências da Engenharia Ambiental) Escola de Engenharia de São Carlos da Universidade de São Paulo, 2007.

1. Valor meio ambiente. 2. Política ambiental.

3. Cenário político econômico. 4 Zoneamento ambiental.

5. Cidade Aracy. I. Título 


\section{DEDICATÓRIA}

Às minhas avós Maria Rita e Henriquetta e aos meus pais, Maria Carolina $e$ Aloysio, que me ensinaram, cada qual a seu modo, a explorar as oportunidades e alternativas disponíveis.

À minha mulher, Maria Célia, pelo estímulo constante, carinho e paciência nos momentos de dificuldade.

Aos meus amigos Regina Cavalcanti de Albuquerque Lemmi, Lemo Lemmi e Rinaldo Hyppólito Júnior, sem cujo precioso e constante auxílio, este trabalho não poderia ter sido realizado. 


\section{AGRADECIMENTOS}

Ao meu orientador, Professor Marcelo Pereira de Souza, pelo voto de confiança $e$ ensinamentos, dados primordiais, sem os quais este trabalho não teria sido realizado.

À Professora Norma Felicidade Lopes da Silva Valêncio, do Departamento de Ciências Sociais da Universidade Federal de São Carlos, pelo privilégio da convivência, que muito me ensinou e pelas retificações sugeridas quando do Exame de Qualificação, fundamentais a este trabalho.

À Biblioteca Central da Escola de Engenharia de São Carlos, da Universidade de São Paulo, em especial à bibliotecária Elena Luzia Palloni Gonçalves, pela inestimável colaboração na correção do trabalho.

À Secretaria da Pós-Gradução do Departamento de Hidráulica e Saneamento da Escola de Engenharia de São Carlos, da Universidade de São Paulo, em especial à Sra. Claudete Aparecida Poianas da Silva, pelo profissionalismo e atenção dispensados todas as vezes que solicitada durante o período que culminou com a realização deste trabalho. 
Nosso Tempo

"Este é tempo de partido,

tempo de homens partidos.

[...] As leis não bastam.

Os lírios não nascem da lei [...]"

(Carlos Drummond de Andrade) 


\section{RESUMO}

FERREIRA NETO, T. B. (2007). Assimilação do valor meio ambiente pela sociedade brasileira. Dissertação (Mestrado) - Escola de Engenharia de São Carlos. Universidade de São Paulo, São Carlos, 2007.

A crise ambiental atual vivida pela sociedade, decorrente da conscientização dos prejuízos advindos da contínua depleção de recursos naturais causada por ação antrópica, introduziu o meio ambiente no cenário político e econômico do mundo. Porém, a preocupação com a preservação ambiental ainda não é compartilhada da mesma forma, pelas sociedades integrantes do planeta. No Brasil, a despeito da legislação vigente sobre o tema, grande parte da população ainda não expressa em seu cotidiano, o "valor meio ambiente", protegido pela Constituição Federal. A compreensão da dicotomia existente entre o que dispõe a legislação ambiental brasileira e o que a sociedade efetivamente expressa acerca do tema, pode ser feita pela história, marcada pelo extrativismo e pelos equívocos decorrentes da idéia de infinitude dos recursos naturais, que permeia desde o período colonial. As questões ambientais estão diretamente ligadas aos interesses de toda a coletividade. Não podem ser analisadas sob o predomínio de individualidades. A correta utilização dos princípios ambientais constitucionais e dos instrumentos de política ambiental, como o Zoneamento e a Avaliação de Impacto Ambiental (AIA), ambos previstos na Lei de Política Nacional do Meio Ambiente (Lei no. 6.938/81), pode auxiliar a difusão e assimilação pela sociedade, do "valor meio ambiente", protegido pelo ordenamento jurídico brasileiro, na medida em que sua aplicação, pode minimizar prejuízos econômicos decorrentes de impactos ambientais, como ilustra o processo de registro do Loteamento Cidade Aracy, na cidade de São Carlos, SP, Brasil.

Palavras-chave: Valor meio ambiente. Política ambiental. Cenário político econômico. Zoneamento ambiental. Cidade Aracy. 


\begin{abstract}
FERREIRA NETO, T. B. (2007). Assimiliation of environmental value by the Brazilian society. M. Sc. (Dissertation) - Escola de Engenharia de São Carlos, Universidade de São Paulo, São Carlos, 2007.

Nowadays, the environmental crisis, experienced by society, resulting from awareness of damages that come from continuous depletion of natural resources caused by human actions, has introduced the environment in the world's political and economic scenery. Nevertheless, concerns about environmental preservation are not shared in the same way by all the global societies. In spite of current legislation in Brazil, a great part of the population does not, ordinarily, express "the environment value" protected by the Constitution. The comprehension of the dichotomy between what the Brazilian environmental law dictates and what society effectively expresses about the theme, may be understood by a History, marked by extractvism and by mistakes derived from the idea of endless natural resources, that has existed since Colonialism. Environmental issues are directly linked to the interests of the entire community. They can not be analyzed exclusively by the predominance of individualities. The correct use of constitutional environmental principles, and also of environmental policy procedures, such as the Environmental Impact Assessment and the Environmental Zoning, may help the diffusion, as well as the assimilation by society of "the environmental value" protected by law, as far as its applicability may minimize economic damages resulting from environmental impacts as illustrated by the process of land division registration in an area named Cidade Aracy, located in São Carlos, Brazil.
\end{abstract}

Keywords: Environmental value. Environmental policy. Economic political scenery. Environmental zoning. Cidade Aracy 


\section{LISTA DE ILUSTRAÇÕES}

Ilustração 1 - Diagrama - categoria de valor

Ilustração 2 - Diagrama - valor meio ambiente

Ilustração 3 - Diagrama - comportamento ético

Ilustração 4 - Vista aérea da Cidade de São Carlos, com destaque ao Loteamento Cidade Aracy

Ilustração 5 - Vista parcial do Loteamento

Ilustração 6 - Córrego da Água Quente

Ilustração 7 - Córrego da Água Quente

Ilustração 8 - Mapa do Loteamento Cidade Aracy

Ilustração 9 - Acesso para pedestres - vista da erosão - Cidade Aracy II

Ilustração 10 - Vista da ponte do acesso para pedestres sobre o Córrego da Água Quente

Ilustração 11 - Mapa do Loteamento Cidade Aracy

Ilustração 12 - Erosão sob a ponte de acesso para pedestres

Ilustração 13 - Emissão de esgoto, sem tratamento, no Córrego da Água Quente

Ilustração 14 - Mapa do Loteamento Cidade Aracy

Ilustração 15 - Vista da erosão localizada nas proximidades da Av. Arnoldo de Almeida Pires

Ilustração 16 - Vista da erosão localizada nas proximidades da Av. Arnoldo de Almeida Pires (outro ângulo)

Ilustração 17 - Mapa do Loteamento Cidade Aracy

Ilustração 18 - Erosão incidente sobre o asfalto em razão das chuvas

Ilustração 19 - Córrego da Água Quente. Ao fundo, aterro da erosão com utilização de entulho de construção civil

Ilustração 20 - Mapa do Loteamento Cidade Aracy 
SUMÁRIO

RESUMO

ABSTRACT

1 INTRODUÇÃO

2 OBJETIVOS 12

3 MATERIAIS E MÉTODOS 13

4 VALOR AMBIENTAL 14

5 HISTÓRIA DO VALOR MEIO AMBIENTE NO BRASIL 18

6 INSTRUMENTOS DO ZONEAMENTO E DA AVALIAÇÃO 37

DE IMPACTO AMBIENTAL

7 EVOLUÇÃO HISTÓRICA DA IDÉIA DE PROPRIEDADE

7.1 LOTEAMENTO - CONCEITO E GENERALIDADES 42

8 ANÁLISE DO PROCESSO DE REGISTRO DO LOTEAMENTO POPULAR CIDADE ARACY

9 CONCLUSÕES 60

REFERÊNCIAS 


\section{INTRODUÇÃO}

A busca de chaves da história passada contribui para explicar o tempo presente (que também faz história), a partir da base de que a primeira condição para modificar a realidade consiste em conhecê-la (GALEANO, 2005, p. 341).

Atualmente, ante um cenário de escassez de recursos naturais e de um processo contínuo de degradação da natureza que só tende a se agravar, estudiosos, de diversas áreas do conhecimento, como por exemplo: Canotilho (Coord.)(1998); Diamond (2005); Garrard (2006); May (Org.) (1995); Sobral (2002); Souza (2000); chegaram à conclusão de que o viver com qualidade depende da otimização da relação do ser humano com o meio em que vive.

Destarte, incluíram a preservação do ambiente na pauta de suas preocupações, cientes de que o meio não está apenas a serviço da humanidade, mas também, se constitui suporte de vida para todos que vivem no planeta.

Outrossim, à medida em que o meio ambiente passou a ser objeto de preocupação, a ele foi conferido dimensão e qualidade, e, via de conseqüência, expressão, inclusive, para a sociedade, aqui vista de forma global.

Com efeito, ao defender e promover o meio em que vive, a sociedade está a assegurar à vida, valor primordial, posto que empenhada na busca de qualidade para viver, o que lhe confere dignidade.

De fato, problemas tais como: destinação dos resíduos sólidos; manejo de ecossistemas; poluição do ar; gestão de recursos hídricos, relacionam-se diretamente com o significativo rol de problemas ambientais vividos por todos, independentemente da situação política, cultural, sócio-econômica e tecnológica.

Além disso, a assunção do meio ambiente como objeto de preocupação permite a construção da cidadania ambiental, que deve ter como paradigma o assegurar ao planeta e 
seus habitantes, o direito de manter sua diversidade biológica e cultural, ou, em outras palavras, assegurar o direito à sustentabilidade ambiental, que, em síntese, busca afastar a concepção reducionista, de que o crescimento econômico deve servir, em caráter exclusivo, como medida para indicação de qualidade de vida.

De fato, como observam Ferreira e Viola (Org.) (1996, p. 10)

[...] uma sociedade sustentável é aquela que mantém o estoque de capital natural ou compensa pelo desenvolvimento do capital tecnológico uma reduzida depleção do capital natural, permitindo assim o desenvolvimento das gerações futuras. Numa sociedade sustentável o progresso é medido pela qualidade de vida (saúde, longevidade, maturidade psicológica, educação, ambiente limpo, espírito comunitário e lazer criativo) ao invés de pelo puro consumo material.

Bem por isso, anota Nalini (2001, p. 138) que

A sustentabilidade importa em transformação social, sendo conceito integrador e unificante. Propõe a celebração da unidade homem/natureza, na origem e no destino comum e significa um novo paradigma. Não há necessidade de se renunciar ao progresso, para a preservação do patrimônio ambiental.

Porém, a despeito do grau de consenso existente hodiernamente, acerca da necessidade de preservação do meio ambiente, verifica-se, como observa Garrard (2006), que tal preocupação não é exatamente compartilhada por diversas sociedades integrantes da Terra, dentre elas, a brasileira.

Com efeito, grande parte da sociedade brasileira ainda não expressa em seu cotidiano, o valor meio ambiente, protegido pelo seu ordenamento jurídico.

As questões ambientais estão diretamente ligadas ao Direito Público, pois disciplinam interesses de toda a coletividade.

Destarte, não há como considerá-las sob o predomínio de individualidades.

Tampouco é possível analisá-las, sob a perspectiva do direito privado, que disciplina o interesse particular dos indivíduos, ou seja, as obrigações que se estabelecem de indivíduo para indivíduo. 
A compreensão da dicotomia existente entre o que efetivamente expressa parte da sociedade brasileira acerca do meio ambiente e o que dispõe o ordenamento jurídico brasileiro a respeito, pode ser efetuada mediante um levantamento histórico, pois, como bem observa Holanda (2006, p. 146) sempre houve, "ao longo de nossa história, o predomínio constante de vontades particulares que encontram seu ambiente próprio em círculos fechados e pouco acessíveis a uma ordenação impessoal."

O presente trabalho se propõe a analisar essa aparente contradição existente, entre o que dispõe a legislação ambiental e o que efetivamente expressa a sociedade, no seu cotidiano, acerca do tema. 


\section{OBJETIVOS}

O objetivo geral é analisar a dicotomia existente entre o que expressa o ordenamento legislativo brasileiro acerca do valor meio ambiente, por ele protegido, e a prática adotada a respeito, pelos atores sociais, particularmente, na esfera municipal, com enfoque na questão imobiliária.

Como objetivo específico, pretende-se utilizar o arcabouço conceitual reunido, para análise do processo de registro do loteamento popular Cidade Aracy, localizado na cidade São Carlos/SP, a fim de demonstrar que a prática adotada pelos setores responsáveis pelo empreendimento imobiliário, não foi pautada pelo que dispõe a legislação ambiental vigente na ocasião. 


\section{MATERIAIS E MÉTODOS}

A metodologia utilizada para realização deste trabalho foi estruturada em pesquisa histórica de base qualitativa, que abrangeu revisão bibliográfica e documental, o que permitiu traçar um paralelo entre eventos históricos ocorridos nos cenários nacional e mundial e promulgação de legislação de interesse ambiental.

Os resultados obtidos, a partir dos elementos analisados, permitiram a análise histórica da assimilação do valor meio ambiente, pela sociedade brasileira.

No tocante ao estudo de caso - loteamento Cidade Aracy - as informações foram obtidas no processo de registro do empreendimento, no Cartório do Registro de Imóveis da comarca de São Carlos/SP, e, de posse dos informes, estes foram analisados à luz do arcabouço conceitual e legal reunido. 


\title{
4 VALOR AMBIENTAL
}

\begin{abstract}
Ambientalismo não é simplesmente um sentimento geral pelo ar puro, pelas espécies em extinção e pelas florestas tropicais. Nesse sentido minimalista, todos são ambientalistas. Em sua base, o ambientalismo é uma ideologia ou uma visão de mundo. Esse paradigma ecológico visualiza um mundo no qual tudo está relacionado com tudo, e, desse ponto de partida, se movem em direção a uma visão coerente do mundo legal, apesar da minha mente perversa (GREVE, 1996, p. 1).
\end{abstract}

Valor, de acordo com Abbagnano (1970, p. 952), é o que "deve ser objeto de preferência ou de escolha."

Segundo Reale (1972), valor vem a ser algo que o ser humano realiza em sua própria experiência e que acaba por assumir expressões diversas e exemplares através do tempo.

Melhor explicando: o ser humano, na busca do significado para sua existência, acaba por escolher e integrar coisas e fenômenos, aos quais confere dimensão ou qualidade.

Em outras palavras, o ser humano, mediante escolhas feitas durante o transcurso de sua existência, acaba por atribuir a certas coisas ou fenômenos, importância ou qualidade.

Ao permitir que o meio ambiente passasse a ser objeto de suas preocupações, o ser humano fez uma escolha, à qual conferiu dimensão e qualidade, e que, por conta disso, assumiu expressão.

Portanto, alçou o meio ambiente à categoria de valor. 


\section{VALOR}

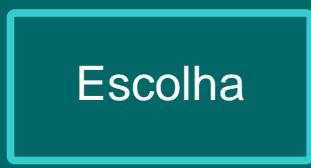

\section{Dimensão}

Qualidade

\section{Categoria de Valor}

Ilustração 1: Diagrama - categoria de valor

Observa Nalini (2001, p. 09-10) que “a compreensão da natureza como nicho vital conduz a consciência humana a ser protetora e vigilante."

Destarte, por alçado o meio ambiente à categoria de valor, o ser humano, com o intuito de expressá-lo e protegê-lo, estabeleceu regras ou leis, para regulamentar suas relações com o meio.

De fato, diversas sociedades integrantes do planeta Terra, representadas por seus legisladores, instauraram, uma vez alçado o meio ambiente à categoria de valor, modelos de organização e conduta para pautarem as relações entre os diversos atores de cada grupo social e o meio ambiente. 


\section{VALOR MEIO AMBIENTE}

\section{Estabelecimento de regras ou leis para proteção}

Regulamentar relação com 0 meio

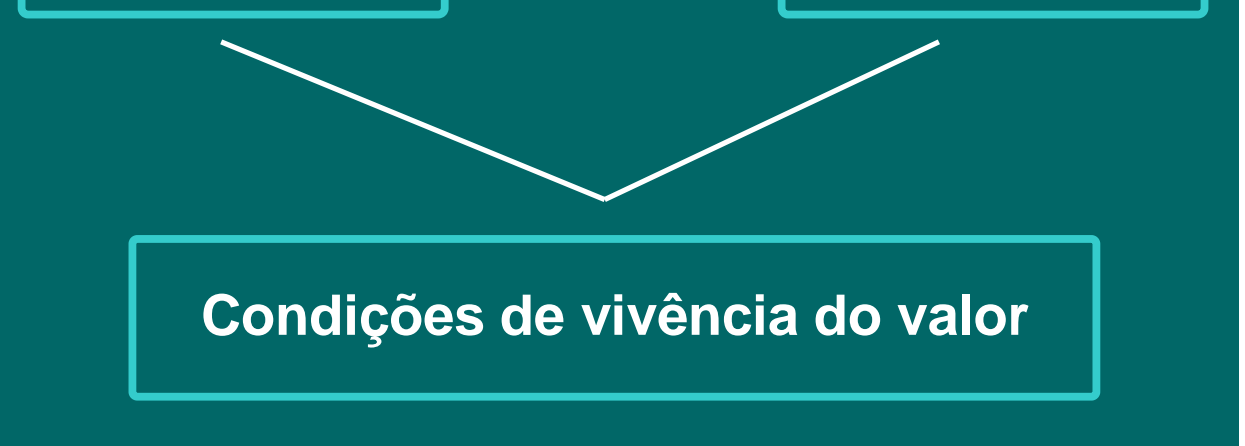

Ilustração 2: Diagrama - valor meio ambiente

Com efeito, posto que "as regras escritas da sociedade na forma de lei regulam efetivamente as relações sociais" (FERREIRA; VIOLA (Org.), 1996, p. 10) e criam, como ensina Reale (2005), condições de realizabilidade garantida do valor (ou valores) por elas protegido, em harmonia com os demais valores sociais.

A vivência concreta, intencional, do valor, é o que se constitui o comportamento ético (FERRY, 2007).

A norma ética, segundo Reale (2005, p. 36), "estrutura-se, pois, como um juízo de dever ser [...] estabelece, não apenas uma direção a ser seguida, mas também a medida da conduta considerada lícita ou ilícita." 


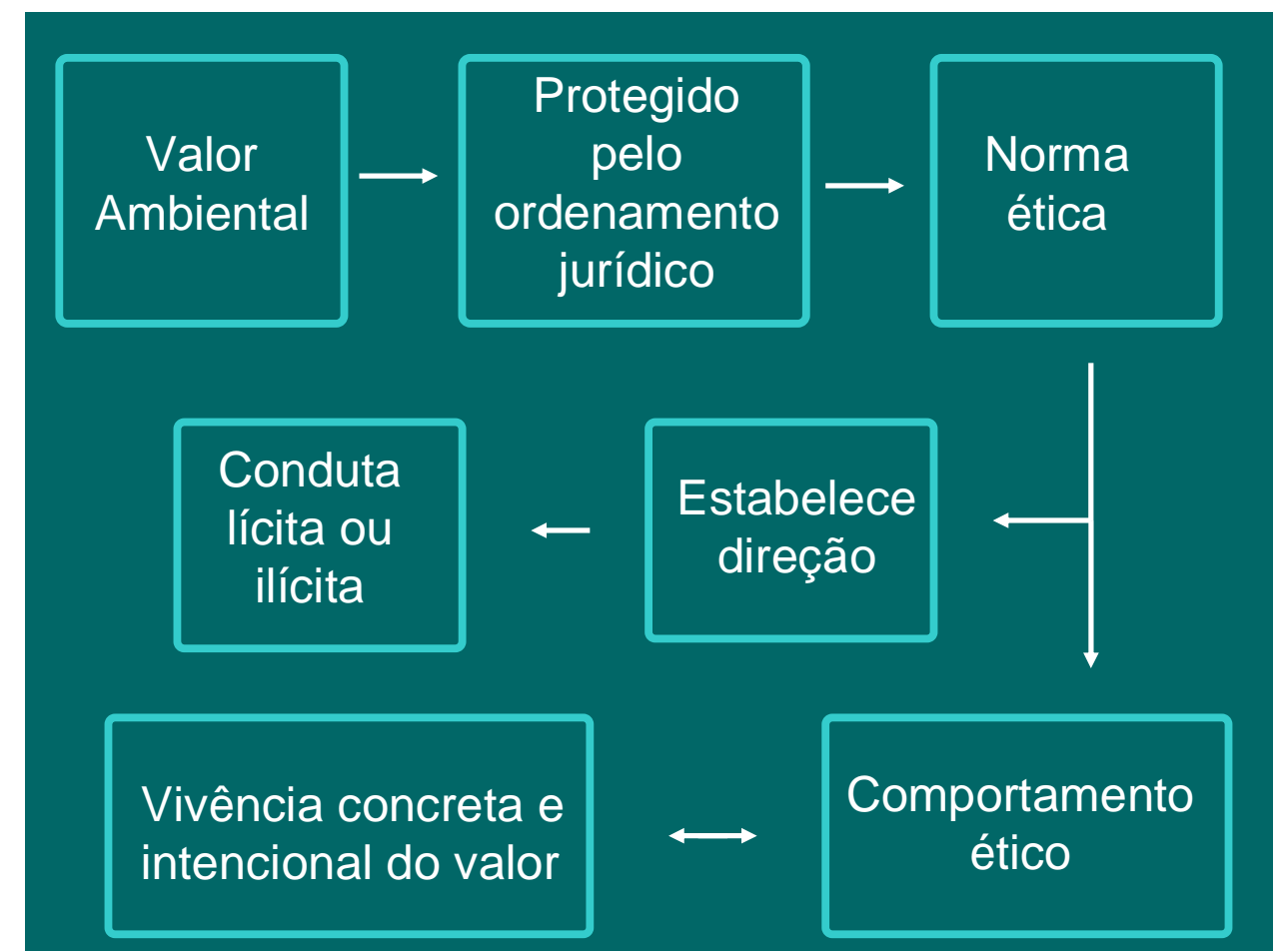

Ilustração 3: Diagrama - comportamento ético 


\title{
5 HISTÓRIA DO VALOR MEIO AMBIENTE NO BRASIL
}

\author{
“Brasil - País do Futuro” (ZWEIG, 1981)
}

No Brasil, o meio ambiente já recebeu, sob o prisma jurídico, o atributo de valor, pois, capítulo específico a respeito, foi incluído na Constituição Federal de 1988 - art. 225 (BRASIL, 1988).

Oportuno destacar que a legislação brasileira ambiental infraconstitucional é considerada "avançada", como observam Viola e Leis (1998, p. 136).

Porém, como já observado, grande parte da sociedade brasileira ainda não expressa em seu cotidiano, o "valor meio ambiente", protegido pelo seu arcabouço legal.

Em outras palavras, no dia a dia, o que se verifica no Brasil, no desenrolar da dinâmica das relações sociais, é que em se tratando do meio ambiente, tema que trata de interesse de toda a sociedade, os interesses coletivos ainda não têm predomínio sobre os interesses individuais.

Como em uma sociedade democrática, os direitos individuais, como bem observam Ferreira e Viola (Org.) (1996) têm correlatos nos deveres individuais e os interesses coletivos têm predomínio sobre os interesses individuais, a dicotomia verificada no Brasil, no que tange a meio ambiente, pode, ao lado de outros fatores, ser explicada mediante um apanhado histórico, pois, segundo Holanda (2006, p. 155), os brasileiros sempre relutaram

[...] em aceitar um princípio superindividual de organização [...] toda nossa conduta ordinária denuncia, com frequiência, um apego singular aos valores da personalidade configurada pelo recinto doméstico. Cada indivíduo, nesse caso, afirma-se ante os seus semelhantes indiferente à lei geral, onde esta lei contrarie suas afinidades emotivas, atento ao que o distingue dos demais, do resto do mundo. 
No mesmo diapasão se manifesta Damatta (2007), quando observa que "as nossas leis são feitas para uma sociedade que tem uma péssima relação com todas as normas que escapam ao contexto, pessoas e situações.”

Não bastasse sua característica personalista, a sociedade brasileira, desde a época da colonização, como observam Holanda (2006) e Pádua (2004), por conta da postura predominantemente extrativista dos portugueses colonizadores, sempre considerou, dada a extensão territorial do país, infinitos seus recursos naturais; idéia permeada pela concepção de que o ser humano é dono e não integrante da natureza. Logo, esta deve estar a seu serviço.

Em outras palavras, durante o período colonial, a conduta predominante no país, no que tange ao meio ambiente, foi a predatória, posto que a relação estabelecida entre os colonizadores e a terra era meramente utilitária.

Não havia o anseio de permanência ou de criação de raízes entre os colonizadores, pois permeava entre eles, o ideal do acúmulo de riquezas, para desfrutá-las em Portugal.

Segundo Holanda (2006, p. 49) “[...]o que o português vinha buscar era, sem dúvida, a riqueza, mas riqueza que custa ousadia, não riqueza que custa trabalho.”

E mais, "todos queriam extrair do solo excessivos benefícios sem grandes sacrifícios.”

Bem por isso, observa Pádua (2004, p. 79) que “a destruição ambiental não foi algo de fortuito e pontual, mas sim um elemento constitutivo da própria lógica da ocupação colonial do Brasil."

Em síntese, relativamente a meio ambiente, pode-se afirmar que o período colonial foi caracterizado pela ausência do anseio de cidadania entre os que aqui viviam, situação comum aliás, a outros valores. 
Durante o Império, período iniciado em 1822, com a proclamação da independência política do Brasil de Portugal, a conduta predatória no que tange aos recursos naturais continuou a ser a tônica dos setores dominantes da sociedade brasileira.

Com efeito, a política era monopolizada, como observa Holanda (2006, p. 73), pelos "fazendeiros escravocratas", em quem, as práticas devastadoras, como acentua Pádua (2004, p. 32) estavam "profundamente arraigadas".

A economia, tal como no período colonial, continuou orientada para a monocultura, dependente da aceitação no mercado europeu.

A cultura cafeeira, que se expandiu durante o Império, exigia, naquela época, basicamente, terra e mão de obra.

Destarte, para aumento de produção, o desmatamento e, como conseqüência, a devastação ambiental, se constituíram regra, posto que a cafeicultura, por seu caráter extensivo, acabou por propiciar o esgotamento do solo onde foi praticada.

Logo, "a vontade de combater a destruição ambiental, que efetivamente existia na mente de alguns, chocava-se com o interesse imediato da elite socioeconômica do país." (PÁDUA, 2004, p. 32).

Realmente, como anota Pádua (2004, p. 10-11), a partir do final do período colonial, teve início, "por parte de pensadores que atuaram no país, entre 1786 e 1888, uma reflexão profunda e consistente sobre o problema da destruição do ambiente natural."

Porém, importante destacar que a reflexão e defesa do meio ambiente feita por alguns, como por exemplo, José Bonifácio e Joaquim Nabuco (Pádua, 2004), não tinha como premissa o meio ambiente como valor em si.

De fato, a valorização do meio ambiente decorria, segundo Pádua (2004, p. 13) de “sua importância econômica e política. [...] Os recursos naturais constituíam o grande trunfo para o progresso futuro do país, devendo ser utilizados de forma inteligente e cuidadosa." 
Destarte, diferentemente do que acontece hoje em dia, a destruição ambiental, na época do Império (séc. XIX), era vista não “[...] como um 'preço do progresso’ ”, mas, sim, como um “preço do atraso" (PÁDUA, 2004, p. 13).

Na Europa, entretanto, no século XIX, exsurgiu, por conta das agressões infligidas pela Revolução Industrial à natureza e aos espaços urbanos, linha de pensamento de cunho naturalista, que, segundo Riechmann e Fernandes ${ }^{1}$ (1994, apud PIERRI, 2005, p. 28):

[...] tem três componentes: o higienismo do século XIX, que reclamava melhoramentos sanitários nas primeiras cidades industriais diante das deterioradas condições de vida dos trabalhadores e conseqüente propagação de doenças para outras classes sociais; o naturismo, que propunha o restabelecimento de uma forma de vida 'natural' como meio de recuperar a 'unidade perdida' entre a humanidade e natureza, por meio de mudanças na conduta individual, e, finalmente, $\mathrm{o}$ conservacionismo de cunho romântico, que se plasma nas primeiras associações nacionais e internacionais protecionistas de espécies animais e espaços naturais virgens.

Tal linha de pensamento, também denominada "crítica naturalista" (PIERRI, 2005, p. 28), se constitui em linhas gerais, a raiz do "ambientalismo contemporâneo."

A República, proclamada em novembro de 1889, não ensejou grande alteração na forma do brasileiro se relacionar com o meio.

Com efeito, a política, durante o período compreendido entre 1889 e 1930, foi dominada pela oligarquia cafeeira, que se valeu do poder para defesa de seus interesses, os quais, não visavam o estabelecimento de uma relação harmoniosa entre o ser humano e o meio.

Pelo contrário, prevaleceu na ocasião, a atitude predatória, permeada pela idéia de infinitude dos recursos naturais.

Por conseguinte, pode-se afirmar que a relação mantida entre a oligarquia cafeeira e a terra, era utilitária, não muito diferente daquela estabelecida pelo colonizador.

\footnotetext{
${ }^{1}$ RIECHMANN, J.; FERNÁNDEZ, B. F. (1994). Redes que dan libertad: introducción a los nuevos movimientos sociales. Barcelona: Paidós.
} 
Em outras palavras, "a crítica naturalista" exsurgida na Europa, não teve grande repercussão no Brasil.

Todavia, não obstante o cenário extrativista da época da Primeira República (1889 a 1930), pela primeira vez, a legislação brasileira, desde a proclamação da independência, tratou especificamente, da preservação ambiental, ainda que visando proteger, não a natureza ou o ambiente propriamente ditos, mas, sim, a propriedade e os conflitos de vizinhança.

Com efeito, o art. 141, do Código de Penal dos Estados Unidos do Brasil, promulgado em 1890, fez referência, como observa Freitas (2005, p. 17), “a ofensa ao meio ambiente, ao punir o ato de incendiar matas ou florestas, pertencentes a terceiros ou à nação.”

O Código Civil, promulgado em 1916, em seu art. 554, assegurou ao proprietário ou inquilino, o direito de impedir que o mau uso da propriedade vizinha viesse a prejudicar a segurança, o sossego e a saúde dos que o habitam (BRASIL, 1916).

Observa Silva (1997, p. 16) que o dispositivo contido no art. 554, do Código Civil de 1916,

[...] possibilitou sólida construção jurisprudencial ampliativa do conceito de vizinhança que passou a significar a zona ou área dentro da qual era sentido o efeito nocivo. Serviu também para fundamentar ação cominatória, visando a impedir a contaminação do meio ambiente por parte de indústrias.

Do Código Civil de 1916 (BRASIL, 1916), por também tratarem de forma reflexa da proteção do meio ambiente, merecem destaque, o art. 572, que estabeleceu limites ao direito de construir e, dentro do mesmo tema (direito de construir), o art. 584, que proibiu construções capazes de poluir, ou inutilizar para o uso ordinário, a água de poço ou fonte alheia, a elas preexistente.

Da época da Primeira República, destaque ainda merece, em matéria ambiental, o Regulamento de Saúde Pública - Decreto 16.300, de 31/12/1923, que, como anota Silva (1997, p. 16), 
[...] criou uma inspetoria de Higiene Industrial e Profissional, entre cujas finalidades se incluíam as de: a) licenciar todos os estabelecimentos industriais novos e bem assim as oficinas, exceto os de produtos alimentícios; b) impedir que as fábricas e oficinas prejudicassem a saúde dos moradores de sua vizinhança, possibilitando o isolamento e o afastamento das indústrias nocivas ou incômodas.

A revolução de 1930 depôs o então presidente da República, Washington Luiz, e pôs fim ao período denominado Primeira República, durante o qual, houve predominância da monocultura (café). Novo modelo de desenvolvimento foi imposto ao país, a partir de então.

De fato, a industrialização ganhou corpo e acabou por se firmar, adotando, a partir de 1950, modelo que subsiste até os dias de hoje, com inflexão das multinacionais.

Todavia, o cenário político-econômico criado a partir de 1930, não afastou dos setores dominantes da sociedade brasileira, a idéia de infinitude dos recursos naturais.

Destarte, o extrativismo e a depleção dos recursos naturais continuaram a permear as relações do brasileiro com o meio ambiente.

Não obstante, em 23 de janeiro de 1934, foi instituído pelo Decreto-lei no 23.793, o Código Florestal (BRASIL, 1934) e, no final da década de 30, do séc. XX, foram criados os primeiros parques nacionais: Itatiaia, Iguaçu e Serra dos Órgãos.

Porém, a edição do Código Florestal em 1934 (BRASIL, 1934), e a criação dos parques nacionais, não tiveram por escopo, o anseio de preservação ambiental propriamente dito, mas, sim, o da afirmação da identidade nacional, que abrange o conjunto de características próprias, exclusivas do país.

Nos anos sessenta, já sob o regime militar que se instaurou no país, a partir de 1964, surgiram textos legislativos de cunho ambiental relevantes, quais sejam: a) o novo Código Florestal - Lei nº 4.771 de 15/09/1965 (BRASIL, 1965), em substituição àquele promulgado em 1934; b) a Lei de Proteção à Fauna - Lei nº 5.197, de 03/01/1967 (BRASIL, 1967a) ; c) o Código de Pesca - Dec-lei no 221, de 28/02/1967 (BRASIL, 1967b). 
Conquanto tais normativos tenham contribuído para assimilação do meio ambiente como valor, ao menos em parte da sociedade brasileira, sua promulgação, principalmente, no que tange ao Código Florestal (BRASIL, 1965), teve como razão principal, a garantia da integridade territorial e não a proteção dos recursos naturais.

Realmente, para os militares, governantes de então, a proteção das florestas, asseguraria a preservação ou salvaguarda do território do país.

Logo, a preservação ambiental e o cenário de depleção dos recursos naturais, ainda não integravam a pauta de preocupações dos governantes ou setores dominantes da sociedade brasileira.

Tanto é assim, que em 1972, como acentua Viola (1996, p. 39-40),

[...] o modelo de desenvolvimento que estava no seu apogeu baseava-se numa forte depleção dos recursos naturais considerados infinitos, em sistemas industriais muito poluentes e na intensa exploração de uma mão-de-obra barata e desqualificada.

Conquanto subsistente no Brasil o modelo de desenvolvimento extrativista; em alguns paises, como Estados Unidos da América, Alemanha, Paises Baixos, ganhou corpo, a partir dos anos 50, do séc. XX, a percepção dos limites físicos do planeta, o que ensejou diversas publicações indicativas da necessidade de tomada de medidas reguladoras do crescimento econômico e populacional, a fim de que fosse evitado um colapso mundial. A respeito, merecem destaque, a publicação em 1962, do livro Primavera Silenciosa da norte americana Rachel Carson, que denunciou o efeito dos agrotóxicos na extinção das aves e, em 1969, o informe "Resources and Man", da Academia Nacional de Ciências dos Estados Unidos da América, que chamou a atenção para o esgotamento dos recursos e a explosão demográfica. Em 1972, por força da Conferência Mundial da Organização das Nações Unidas sobre o Meio Humano, realizada em Estocolmo, Suécia, no período compreendido entre 05 a 16 de junho de 1972, a crise ambiental foi efetivamente introduzida no cenário político e econômico do mundo. 
Com efeito, como observa Pierri (2005, p. 32),

A ênfase da Conferência foi dada pelos países desenvolvidos e colocada sobre os problemas da contaminação causada pela acelerada industrialização e urbanização, e pelo esgotamento dos recursos naturais, atribuídos ao descontrolado crescimento populacional. Assim, além da necessidade de gerar e aplicar tecnologias limpas, sugeriam deter ou reduzir o crescimento populacional e econômico.

A Declaração de Estocolmo sobre o Meio Ambiente, feita em 16 de junho de 1972, fez com que o "[...] vínculo entre o desenvolvimento e a sustentabilidade [...]” entrasse “[...] no rol das preocupações e metas dos governantes [...]”, como anota Freitas (2005, p. 233).

O Brasil e outros países do Terceiro Mundo participantes da conferência, não aceitaram as sugestões de controle apresentadas em Estocolmo, sob o argumento de que

[...] os problemas ambientais que motivavam a reunião eram dos países ricos, causados por seus excessos de produção e consumo, e que se ali eram considerados problemas era porque já tinham se desenvolvido e desfrutavam um bom nível de vida. Também entendiam que o verdadeiro problema era que dois terços da humanidade estava dominado pela pobreza, má nutrição, doenças e miséria. Portanto, tratava-se de priorizar o desenvolvimento, razão pela qual a filosofia do não-crescimento era absolutamente inaceitável (PIERRI, 2005, p. 32).

Segundo Viola (1996, p. 41),

[...] apesar das profundas transformações que aconteceram no mundo, nas décadas de 1970 e 1980, a posição do Itamarati permaneceu vinculada às posições nacionalistas de Estocolmo. A noção de incompatibilidade entre desenvolvimento e proteção ambiental passou a ser uma questão de princípio para a diplomacia brasileira. Costumava-se considerar o argumento ambientalista como uma estratégia do Norte para impor um destino subdesenvolvido ao Sul; para justificar a ingerência internacional em assuntos internos.

Embora predominante no Brasil, cenário de incompatibilidade entre

desenvolvimento econômico e preservação ambiental; em 14 de agosto de 1975, foi editado o

Decreto-lei no 1413 (BRASIL, 1975) que, segundo Freitas (2005, p. 21),

[...] pode ser considerado o primeiro diploma brasileiro de objetiva proteção ambiental. Dispõe ele, no art. $1^{\text {o: }}$ 'As indústrias instaladas ou a se instalarem em território nacional são obrigadas a promover as medidas necessárias a prevenir ou corrigir os inconvenientes e prejuízos da poluição e da contaminação do meio ambiente.' 
Consigne-se que o Decreto-lei no 1413/75 (BRASIL, 1975) foi promulgado, para atender a exigência feita pelo "Water Criteria Act", pelo qual, os Estados Unidos da América, deliberou que os países que não têm os mesmos cuidados que eles no campo de tratamento de efluentes e na área ambiental poderão, para compensar, ter seus produtos taxados no mercado americano.

Outrossim, em 31 de agosto de 1981, foi promulgada a Lei ${ }^{\circ} 6.938$ (BRASIL, 1981), que dispôs sobre a Política do Meio Ambiente, seus fins e mecanismo de formulação e aplicação e deu outras providências.

Importante anotar que tal normativo chegou a formular, em seu art. $3^{\circ}$., inc. I, conceito de meio ambiente.

A promulgação da Lei de Política do Meio Ambiente foi um grande passo para disseminação da problemática ambiental na sociedade brasileira, pois o normativo, como assinala Dinamarco (1988, p. 26), introduziu o conceito de "lesão ambiental, considerada da ótica solidarista que caracteriza o direito de massa."

Prosseguindo, anota Dinamarco (1988, p. 26), que

Não se trata mais de repelir somente os danos causados aos indivíduos, enquanto tais, mas o dano que, com a agressão ao meio ambiente, é causado a toda a comunidade. Essas idéias tornaram-se bastante conhecidas e integraram-se num contexto muito fecundo de estudos sobre os chamados interesses difusos. São interesses supra-individuais, indivisíveis e insuscetíveis de personificação; interesses que, justamente porque arredios à referência a um específico centro de imputação, pertencem a todo um grupo de pessoas ligadas por algum aspecto da vida em comum. E a lesão aos bens assim ligados ao grupo será, antes de mais nada, uma lesão ao próprio grupo. A lei de 1981 foi capaz de introduzir, assim, a dicotomia representada pela lesão individual e lesão ambiental; e essa dicotomia é de extrema relevância no equacionamento da proteção jurisdicional ao meio ambiente.

Necessário destacar que a Lei de Política do Meio Ambiente brasileira foi promulgada em época que no mundo, cresceu com muita força, a conscientização de que os problemas ambientais, como observa Sobral (2002, p. 140), "não respeitam fronteiras políticas e que o enfrentamento de questões ambientais exige, sobretudo, ações locais."

Destarte, ainda conforme Sobral (2002, p. 140), o 
[...] mote Pensar Globalmente, Agir Localmente, tornou-se a palavra de ordem mais freqüente em encontros, publicações e campanhas ambientalistas. Paralelamente, foram se desenvolvendo ações visando colocar em prática este lema. Os municípios e governo locais, em todo o mundo, passaram a se preocupar e a desenvolver políticas ambientais; as Organizações Não Governamentais voltaram a mobilizar os cidadãos para agirem em seus locais de moradia, estudo ou trabalho, visando o bemestar comum da humanidade.

Em outras palavras, o planeta Terra deixou de ser

[...] apenas um ente astronômico, mas também histórico. O que parecia, ou era, uma abstração, logo se impõe a muitos como realidade nova, pouco conhecida, com a qual há que conviver. O planeta Terra torna-se território da humanidade (IANNI, 1996, p. 93).

A globalização em muito contribuiu para difusão da problemática ambiental, nas diversas sociedades integrantes do planeta.

Destarte, independentemente da subsistência do ideário extrativista e da dificuldade de assimilação de princípio superindividual de organização, o meio-ambiente passou a integrar com maior força, a pauta de preocupações de alguns setores decisórios da sociedade brasileira, a ponto de ser consagrado como valor, pela Constituição Federal.

Em 05/10/1988, foi promulgada a vigente Constituição Federal (BRASIL, 1988), que incluiu em seus dispositivos (art. 225 e incisos), capítulo específico acerca do meio ambiente e a ele, como acima observado, conferiu o atributo de valor.

O meio ambiente também foi inserido no capitulo dos Princípios Gerais da Atividade Econômica da Constituição Federal (art. 170, inc. VI) e no art. 186, inc. II, que assegura a função social da propriedade rural (SABATOVSKI; FONTOURA (Org.), 2000, p. $110-111 ; 118)$.

Segundo Nalini (2001, p. 25), a “carta de 1988 é eminentemente principiológica. Essa opção permite constante reinterpretação do texto fundante, garantindo a todos os seus aplicadores venham a contribuir na concretização normativa do constituinte." 
Os princípios acolhidos pela Constituição Federal em matéria ambiental, servem, como bem observa Fortunato Neto $(2004$, p. 39) “[...] de diretriz e orientação, reconhecíveis mesmo quando não agasalhados por sistemas jurídicos [...]"

A assimilação de tais princípios e sua utilização, na atividade legislativa afigurase, pois, imprescindível, para que haja, tal como desejado pelo constituinte, em caráter contínuo, implementação de políticas públicas que permitam a conciliação do crescimento econômico permeado pela necessidade de sustentabilidade.

Dentre os princípios acolhidos pela Constituição Federal merecem destaque os seguintes:

1) Princípio da Sustentabilidade

Ao assegurar a todos, em seu art. 225, o direito ao meio ambiente ecologicamente equilibrado, a Constituição Federal (BRASIL, 1988) acabou por afastar a concepção de que o crescimento econômico deve servir, em caráter exclusivo, como medida para indicação de qualidade de vida.

Com efeito, a partir de outubro de 1988, no Brasil, a busca de novas formas de relação entre o ser humano e o seu ambiente, passou a envolver uma dimensão ética, afastada da preocupação de manutenção da exigência de avanço permanente da produção.

Como bem observam Fiorillo e Rodrigues (1997, p. 119), livre concorrência e defesa do meio ambiente caminham "lado a lado para o alcance da ordem econômica voltada para justiça social."

Acrescentam que "acentua-se aí, a adoção ao desenvolvimento sustentado, com o fim de preservar o hoje e o amanhã (futuras gerações)." 
Portanto, sustentabilidade deve envolver a vivência contínua da questão ambiental, vista como esforço para manutenção e recuperação das condições necessárias para que a terra continue a potencializar a propagação da vida sobre ela.

Não por outra razão, Granziera (2003) observa que desenvolvimento sustentável é um princípio atinente a toda política ambiental, pois possui interfaces com a outorga do direito de uso da água, o licenciamento ambiental, os usos múltiplos, a noção de bacia hidrográfica como unidade de planejamento.

\section{2) Princípio da Prevenção}

O princípio da prevenção eleva, como bem observa Tupiassu (2003, p. 171), “[...] a um grau mor a necessidade de planificação das atividades, visando a garantia da qualidade de vida não apenas para o presente, mas abarcando a sociedade futura.”

Enfatizando a necessidade de planificação, busca-se impedir a ocorrência de danos ao meio ambiente.

\section{3) Princípio da Precaução}

O princípio da precaução significa, segundo Canotilho (Coord.) (1998, p. 48-49),

[...] que o ambiente deve ter em seu favor o benefício da dúvida quando haja incerteza, por falta de provas científicas evidentes, sobre o nexo causal entre uma actividade e um determinado fenómeno de poluição ou degradação do ambiente. Pode-se falar a este propósito, de uma espécie de princípio 'in dubio pro ambiente'.

Complementando, Granziera (2003, p. 49) anota que

[...] como um passo posterior ao desenvolvimento sustentável, e ao princípio da prevenção, o princípio da precaução pende para a 'não-ação', ao 'nãodesenvolvimento', toda vez que se entender, no caso concreto, que essa ação - ou esse desenvolvimento - pode causar danos irreversíveis ao meio ambiente. 


\section{4) Princípio do Poluidor-Pagador}

Tal princípio, como observa Nalini (2001), acentua a necessidade do poluidor suportar os gastos decorrentes dos danos ambientais. Trata-se, pois, de princípio preventivo.

Em outras palavras, os poluidores devem levar em conta, quando da elaboração de seus projetos econômicos, os prejuízos que sua atividade causa ao meio ambiente e consequentemente, à sociedade.

Tal avaliação fará com que o empreendedor acabe por escolher a opção que lhe for mais adequada economicamente:

a) evitar a atividade poluidora ou;

b) manter a atividade, arcando, entretanto, com os custos decorrentes dos danos ambientais que acabaria por provocar.

A inserção em planejamento econômico dos custos impostos pela atividade poluidora, implica, como observa Canotilho (Coord.) (1998, p. 53), no desempenho de

[...] função que, em linguagem económica, se denomina internalização da externalidades ambientais negativas. Actividades geradoras de externalidades negativas são aquelas que impõem custos a terceiros independentemente da vontade destes e também independentemente da vontade de quem desenvolve essas actividades.

\section{5) Princípio da Participação}

Tendo a Constituição Federal assegurado a toda coletividade direito ao meio ambiente ecologicamente equilibrado, a todos incumbe, como consta do texto legal, o dever de preservá-lo e defendê-lo. 
Para que seja assegurado a todos o exercício de seu direito e dever, é necessário que se garanta à população, como observa Tupiassu (2003), a possibilidade de manifestação, quando da formulação e execução de políticas ambientais.

Note-se porém, que a manifestação está condicionada à informação, pois, não há possibilidade de participação, sem que antes haja informação.

Logo, o direito de participação é corolário do direito de informação.

6) Princípio da Cooperação

Consiste na busca pelas nações, de ações conjuntas e de políticas que visem correção ou prevenção de danos ambientais, tendo como resultado a garantia de benefícios a todos os ambientes do planeta.

Tal princípio, como anota Tupiassu (2003), está escudado na presunção de que o ambiente é um bem coletivo. Em assim sendo, é dever de todos protegê-lo, em respeito à convicção de que tanto a atual, como as próximas gerações, têm direito a vida com qualidade.

Porém, apesar do meio ambiente ter atingido, quando da promulgação da Constituição Federal de 1988, inclusive por conta do acolhimento de princípios, a condição, segundo Nalini (2001, p. 1) de "valor invariável para o futuro", o governo federal e grande parte da sociedade brasileira mantinham de acordo com Viola (1996, p. 41), "uma postura defensiva em relação às questões ambientais”, postura essa que perdurou durante quase todo o período do governo Sarney, o que motivou críticas internacionais.

Pressionado por críticas internacionais acerca de sua gestão na área ambiental o governo Sarney criou o IBAMA (Instituto Brasileiro do Meio Ambiente e dos Recursos Naturais Renováveis) (BRASIL, 1989), o que implicou numa, segundo Viola (1996, p. 42), “[...] reforma conceitual-organizacional na definição da problemática ambiental, já que pela 
primeira vez associa-se a proteção ambiental ao uso conservacionista de alguns recursos naturais."

O Governo Collor, que teve início em março de 1990, para por em prática o seu plano de estabilização econômica, dependida, dentre outros requisitos, da vinda de investimentos estrangeiros ao país.

Segundo Viola (1996, p. 45),

[...] logo depois de eleito, Collor percebeu imediatamente que a ênfase na proteção ambiental era provavelmente sua maior moeda de troca na nova parceria pretendida com o Norte. Além disto, Collor também percebeu que a escolha do Brasil para sediar a UNCED-92, por parte da Assembléia Geral da ONU, efetuada poucos dias depois de sua eleição, dava-lhe uma grande oportunidade para projetar sua pessoa e seu governo no cenário internacional.

A Conferência das Nações Unidas para o Meio Ambiente e o Desenvolvimento, também denominada Rio-92 ou ECO-92, realizada na cidade do Rio de Janeiro, em junho de 1992, é uma referência no debate ambiental mundial, instaurado desde a Conferência de Estocolmo.

Várias questões ambientais foram debatidas, merecendo ênfase: a) os mecanismos que promovam o desenvolvimento sustentável; b) a biodiversidade e sua proteção; c) o efeito estufa; d) a soberania das florestas.

Ressalta Viola (1996, p. 48), que

[...] a posição brasileira na UNCED pode ser enquadrada como um tênue globalismo-progressista-sustentabilista inserido numa estrutura estatal em que predominam o Nacionalismo-conservador (declinante) e o globalismo-conservador (ascendente).

Comentando os resultados da Rio-92, Viola e Leis (1998, p. 139), observam que

[...] houve simultaneamente um avanço extraordinário no plano simbólico e de conscientização - o 'espírito do Rio' de que fala Strong, com a sustentabilidade ambiental tendo adquirido um peso extraordinário como princípio de legitimidade do mundo contemporâneo. Também houve um fracasso no plano político-econômico refletido na incapacidade de construir-se marcos de referências, mecanismos de implementação e instituições correspondentes à nova consciência e legitimidade. 
Em outras palavras, a partir da Rio-92, a conscientização da questão ambiental vem crescendo de forma constante e paulatina no Brasil, o que assegura a manutenção do discurso e da normatização a respeito.

Porém, como anotam Viola e Leis (1998, p. 136),

[...] os comportamentos individuais estão muito aquém dos discursos, sendo muito poucas as pessoas (inclusive entre os ambientalistas militantes) que pautam conscientemente seu cotidiano pelos critérios da eficiência energética, reciclagem de materiais, redução do consumo suntuário e participação voluntária em tarefas comunitárias de limpeza ambiental. As políticas públicas estão hoje a meio caminho entre um discurso-legislação bastante ambientalizados e um comportamento individual-social bastante predatório, sendo que, por um lado, as políticas públicas têm contribuído para estabelecer um sistema de proteção ambiental no país, mas, por outro, o poder político é incapaz de fazer os indivíduos e as empresas cumprirem a uma proporção importante da legislação vigente.

Em resumo, de acordo com Viola e Leis (1998), no Brasil, em matéria ambiental, existe contradição entre discurso e ação.

Tal dicotomia permite a conclusão, a que já chegaram outros autores, tais como Freitas (2005), Nalini (2001), de que no Brasil, apesar de toda a evolução experimentada pelo assunto, a expressão ou vivência perene pela sociedade, do valor meio ambiente, protegido pela Constituição Federal (art. 225) (BRASIL, 1988), bem como a conscientização da necessidade da preservação ambiental, se constituem condições a serem alcançadas e não realidade.

Em outras palavras, em matéria de prática e cumprimento pela sociedade, do que dispõe a legislação ambiental, o Brasil é um país do futuro.

A partir do momento em que a preocupação com a questão ambiental ganhou força no cenário mundial, diversos setores decisórios da sociedade brasileira, tais como, as universidades, parte do Poder Legislativo, o Ministério Público, o Poder Judiciário, as organizações não-governamentais, se sensibilizaram para o tema e vêm procurando de forma sistemática, inseri-lo, tanto através de sua normatização; tanto através de sua vivência e expressão, na sociedade. 
Porém, tal intento ainda não logrou êxito completo, pois, para grande parte da sociedade, que abrange setores dominantes, como por exemplo, parcela do empresariado e integrantes do Poder Executivo, preservação e progresso são incompatíveis. O espaço físico não ocupado, para tais setores, como observa Garrard (2006, p. 34), continua a não merecer maiores considerações, "exceto na medida em que ele possa ter um impacto na riqueza ou no bem-estar humanos. A natureza só é valorizada em termos de sua utilidade para nós.”

Resumindo, a visão utilitária do meio continua, tal como foi ao longo de nossa história, bem presente entre nós.

Outrossim, para grande segmento da sociedade brasileira subsiste a idéia de infinitude dos recursos naturais, presente desde a época da colonização, pois, para quem integra tal segmento, segundo observa Garrard (2006, p. 33),

[...] a suposta escassez de recursos naturais é desmentida pela queda de preços dos alimentos, dos minerais e das commodities em relação aos salários; à medida que um recurso específico torna-se mais difícil de obter, seu preço aumenta, levando os empresários capitalistas a buscar fontes, processos ou materiais que o substituam. A descoberta de alternativas leva a uma redução do preço do material original, como ocorreu na queda dos fios do cobre, acarretada pela ampla substituição dos fios de cobre por cabos de fibra óptica. A 'escassez', portanto, é um fenômeno econômico, não ecológico, e será remediada por empresários capitalistas, e não pelas reduções do consumo insistentemente pleiteadas pelos ambientalistas.

De outro lado, em razão das sucessivas crises econômicas pelas quais passou o país, no desenrolar de sua história, decorrentes inclusive, dos modelos econômicos adotados, de cunho manifestamente extrativista, grande parte dos brasileiros permanece excluída do mercado e, por conseguinte, impossibilitada do efetivo exercício de cidadania, posto que envolvida na busca da satisfação de suas necessidades primárias.

Para tal grupo, a questão ambiental afigura-se como algo remoto, distante de suas preocupações.

Em suma, atualmente no Brasil, permeando a questão ambiental encontram-se interesses conflitantes. 
A conduta do Poder Público no Brasil, por conta da dicotomia social existente acerca da questão ambiental, acaba por se circunscrever, nem sempre de forma bem sucedida, ao controle de impactos ambientais e atividades econômicas.

Em outras palavras, o Poder Público brasileiro ainda não conseguiu fazer com que os serviços ambientais sejam vistos por todos, como ganho de capital, o que acaba por dificultar a assimilação do meio ambiente como valor.

Porém, apesar da existência de interesses conflitantes em matéria ambiental, vem ganhando espaço na sociedade brasileira, a idéia da possibilidade de conciliação do desenvolvimento econômico e proteção ambiental.

Segundo Freitas (2005, p. 233),

Daí o surgimento da tentativa de ligar os interesses, desenvolvimento e proteção ao meio ambiente, fazendo com que a utilização dos recursos naturais fosse feita com critério, de modo a preservá-los. Isto é o que se convencionou chamar de desenvolvimento sustentável.

Nalini (2001, p. 138) anota que

A sustentabilidade importa em transformação social, sendo conceito integrador e unificante. Propõe a celebração da unidade homem/natureza, na origem e no destino comum e significa um novo paradigma. Não há necessidade de se renunciar ao progresso, para a preservação ambiental.

E, acrescenta: “O desenvolvimento sustentável pretende promover o bem-estar das pessoas sem transigir com a degradação do capital natural” (NALINI, 2001, p. 141).

Não se pode esquecer que o chamado desenvolvimento sustentável ou política de desenvolvimento sustentável também é objeto de críticas, pois, independentemente da convivência por ela proposta entre desenvolvimento econômico e preservação, subsiste a idéia de que ela pode manter, ainda que de forma controlada, a destruição dos recursos naturais.

Porém, como observa Freitas (2005, p. 246),

[...] não se pode afastar a conclusão de que as pessoas estão habituadas a um sistema de vida que lhes proporciona conforto e comodidade. E nisso não se está a falar apenas das classes sociais mais favorecidas, mas também das pessoas que contam com poucos recursos para a sua própria sobrevivência. É de se perguntar quantos 
hoje, no Brasil, se sujeitariam a renunciar ao ar condicionado, a afastar de sua alimentação produtos feitos com o uso de agrotóxicos, a limitar a descarga de água de seu banho a um minuto e meio, a subir vários andares de seu edifício sem o uso do elevador ou a abrir mão de móveis de madeira. O que se quer dizer é que a proteção ambiental exige a participação de todos e não basta criticar as conseqüências do desenvolvimento sobre o meio ambiente. Antes, é necessário colocar o desenvolvimento dentro de limites que protejam a natureza, sob pena de em certo momento ter-se que abrir mão de benefícios alcançados com o progresso e que hoje já fazem parte dos hábitos da maior parte da população brasileira.

Sustentabilidade implica, pois, em esforço para abdicar do pensar o econômico, o social, o ambiental, de forma estanque.

Com efeito, posto que o meio ambiente, como observa Cavalcanti (1996, p. 319),

[...] e também a sociedade, são entidades 'naturais', no sentido de que independem do propósito humano, o primeiro tendo uma existência autônoma que precede ao aparecimento da segunda. Assim, o sistema econômico, que é uma ferramenta da sociedade, não passa de um subsistema aberto do ecossistema, precisando dele vitalmente como fonte supridora de recursos e como espaço onde faz o lançamento dos dejetos resultantes das atividades produtiva e de consumo. Está assim irremediavelmente vinculado aos princípios e leis de funcionamento da ecosfera, princípios e leis esses que, como mostram as ciências da natureza, não admitem exceção.

Resumindo, sustentabilidade envolve a idéia de integração. 


\title{
6 INSTRUMENTOS DO ZONEAMENTO E DA AVALIAÇÃO DE IMPACTO
}

\section{AMBIENTAL}

\author{
“Um Sopro de Esperança”" (ALLENDE, 2005)
}

A Lei Federal nº 6.938/81 (BRASIL, 1981) que dispôs sobre a Política Nacional do Meio Ambiente, criou, como pode ser verificado em seu art. $9^{\circ}$, uma série de instrumentos, que, uma vez corretamente aplicados, podem contribuir para conciliação de desenvolvimento econômico, com preservação ambiental.

Dentre tais instrumentos, merecem destaque, a Avaliação de Impacto Ambiental (AIA) e o Zoneamento Ambiental.

A Avaliação de Impacto Ambiental, segundo Sanchez (1995, p. 13),

[...] tem sido vista como um instrumento de planejamento, isto é, como um instrumento de prevenção do dano ambiental e como um procedimento definido no âmbito das políticas públicas, usualmente associado a alguma forma de processo decisório, como o licenciamento ambiental. Estas duas dimensões da AIA são indissociáveis e, no conjunto, seu objetivo pode ser formulado como o de analisar a viabilidade ambiental de um projeto, plano ou programa.

Acrescenta Sanchez (1995, p. 13), que

[...] a Avaliação de Impacto Ambiental vista como um instrumento de planejamento é entendida como uma atividade de caráter técnico-científico como o objetivo de identificar, prever e interpretar as consequiências sobre o meio ambiente de uma dada ação humana.

[...] ]enquanto procedimento inserido no âmbito de uma política ambiental, pode ser melhor definida como um conjunto de procedimentos que envolve entre outros, (I) a determinação da necessidade de uma dada iniciativa ser submetida à AIA; (II) o estabelecimento de termos de referência para condução de um estudo específico; (III) a elaboração de um estudo de caráter técnico denominado EIA; (IV) a preparação de um documento de comunicação denominado RIMA; (V) mecanismos formais de participação do público, como a audiência pública; (VI) procedimentos de análise técnica e de revisão dos estudos apresentados e (VII) um procedimento formal de tomada de decisão. O termo processo de Avaliação de Impacto Ambiental é também empregado como sinônimo deste conjunto de procedimentos.

Já o Zoneamento Ambiental segundo Oliveira (2004, p. 45), é

[...] um instrumento cuja finalidade é auxiliar a formulação de políticas e estratégias de desenvolvimento, o que possibilita a visualização, por meio de cenários, da 
distribuição das áreas suscetíveis a processos naturais e também das áreas com maior ou menor potencial para a implantação de atividades, de forma bastante clara [...]

Em outras palavras, o Zoneamento Ambiental, como observa Montaño (2002), indica as possibilidades de uso antrópico de determinada área, pois, através da montagem de cenários, fragilidades ambientais são definidas, e via de conseqüência, é mapeada a capacidade de assimilação de impacto.

Bem por isso, Silva (1997, p. 181), anota que “o zoneamento é um instrumento jurídico de ordenação do uso e ocupação do solo."

O grande desequilíbrio sócio-econômico-cultural interno verificado atualmente na sociedade brasileira pode prejudicar a disseminação do meio ambiente, como valor.

Com efeito, o apelo à subsistência, o que implica em satisfação de necessidades primárias dificulta não só a assimilação, mas, também, a busca da sustentabilidade ambiental em seu contexto mais amplo.

A idéia de que os serviços ambientais não ensejam ganhos de capital, também acaba por dificultar a assimilação do meio ambiente como valor.

Tais posicionamentos, além de reducionistas, são equivocados, pois, a adequada utilização de instrumentos de política ambiental pode ensejar a minimização de desequilíbrios sócio-econômico-culturais, como também, pode propiciar de forma mais célere e racional, o desenvolvimento dos diversos grupos que compõem a sociedade brasileira.

Com efeito, na teoria de Maslow (1970), comentada por Krech e Crutchfield (1971, p. 314-315)

[...] o curso 'natural' do desenvolvimento envolve uma 'expansão' gradual das necessidades e dos atributos essenciais da natureza humana, uma série contínua de estádios através dos quais a pessoa passa, ao avançar para níveis cada vez mais altos de motivos e organização.

Especificamente, Maslow concebe os cinco seguintes níveis de necessidades, organizados numa escala que vai das 'necessidades inferiores' às 'necessidades mais elevadas':

Necessidades fisiológicas, tais como satisfazer fome, sede.

Necessidades de segurança, tais como estabilidade, ordem, confiança.

Necessidades de participação e amor, tais como afeição, identificação. 
Necessidades de consideração, tais como prestígio, êxito, auto-respeito.

Necessidades de auto-realização.

Os termos 'inferiores' e 'superiores' indicam, apenas, que algumas necessidades se manifestam mais cedo no processo de desenvolvimento, estão mais estreitamente ligadas às necessidades biológicas, são mais limitadas em seu alcance.

Evidentemente, não existem, no desenvolvimento psicológico, passos nítidos e descontínuos - cada uma das necessidades "inferiores" não precisa ter sido inteiramente satisfeita para que surja a necessidade "superior" seguinte. Assemelha-se mais a uma sequiência de ondas, na qual se desloca, gradualmente, a relativa saliência das diferentes necessidades.

“O ambiente físico e social ótimo é aquele que torna possível a satisfação de cada nível de necessidades" (KRECH; CRUTCHFIELD, 1971, p. 315).

Ora, se ambiente físico ótimo é aquele que torna possível a satisfação de cada nível de necessidades, afigura-se claro que o Poder Público deve diligenciar para formulação de políticas que permitam o surgimento de tal espaço, adotando, para tanto, instrumentos de planejamento já previstos na Lei de Política Ambiental (Lei nº 6938/81) (BRASIL, 1981) que permitam a consecução de tal objetivo de forma concatenada e, conseqüentemente, mais rápida.

Importante anotar que política, como observa Souza (2000, p. 34), “[...] é um processo por meio do qual interesses levam à formulação de decisões e ações significativas que sejam levadas adiante, de modo a modificar situações dentro da sociedade.”

Ora, se o Zoneamento Ambiental indica as possibilidades de uso antrópico de determinada área, através da montagem de cenários, dúvida não há de que sua utilização, como observa Souza (2000, p. 39) “[...] daria um dinamismo muito maior à aplicação de diversos instrumentos e mecanismos de política ambiental [...]” e, conseqüentemente, otimizaria a aplicação de processos aptos a modificarem situações dentro da sociedade. 
Destarte, pretendendo o Brasil mudar o seu modelo de desenvolvimento, para adotar o chamado "desenvolvimento sustentável", necessário que se estimule, como observa Souza (2000, p. 94),

[...] educação (formal e não-formal) dos cidadãos e o incentivo à promoção do zoneamento ambiental em todo o território nacional, com o objetivo de direcionar os processos de produção do espaço, dando prioridade à manutenção da qualidade ambiental. Embora existam iniciativas pontuais em todo o país, inclusive da sociedade, o zoneamento é um instrumento que se apresenta ainda em estágio incipiente. A implementação desse e de outros instrumentos - merece destaque a avaliação de impacto ambiental (AIA) -, assim como consecução das etapas de gestão ambiental, são fundamentais para o desenvolvimento sustentável.

Importante observar que o sistema jurídico, assim como o sistema econômico, são ferramentas da sociedade, não passando, como acentuado por Cavalcanti (1996) de subsistemas abertos do ecossistema.

Anota Freitas (2005, p. 24), que

[...] o Direito Ambiental, mesmo sendo autônomo, é dependente dos tradicionais ramos do Direito. Com efeito, é impossível imaginar o Direito Ambiental alheio ao Constitucional, ao Civil, ao Penal e ao Administrativo. Mas é impossível também entendê-lo como mera fração, parte de qualquer da vertentes citadas. É preciso, pois, encará-lo como algo atual, fruto das condições de vida deste final de milênio e, por isso mesmo, dotado de características e peculiaridades novas e incomuns.

A correta aplicação dos instrumentos de política ambiental, constitui a esperança (que não é realidade, mas promessa de) para implementação do chamado desenvolvimento sustentável. 


\title{
7 EVOLUÇÃO HISTÓRICA DA IDÉIA DE PROPRIEDADE
}

A propriedade tem raízes na Pré-história e dela não se descuidaram os ordenamentos jurídicos da Antiguidade.

Porém, foi a Revolução Francesa, como observa Pereira (1994), que a inscreveu entre os direitos naturais e imprescritíveis do ser humano.

Bem por isso, o Código Civil francês, editado na primeira metade do séc. XIX, informou segundo Lopes (1960, p. 241), “[...] a idéia de propriedade sob um aspecto profundamente individual e não admitiu a sua indivisão senão sob o aspecto de condomínio."

Outrossim, o legislador francês conferiu à propriedade caráter absoluto, o que assegurava ao proprietário, o direito de, em toda sua plenitude, usar e gozar da coisa.

Segundo Pereira (1994, p. 28), o jurista francês

\begin{abstract}
“[...] classificou, numa espécie de aristocracia bonitária, a coisa imóvel como a mais importante, porque a propriedade imobiliária traduz mais que outra qualquer a idéia de assenhoreamento, de conservação e de equilíbrio econômico. Aquele a quem pertencem mais coisas tem uma importância social maior. Descrente da aristocracia de linhagem, a sociedade moderna constituiu uma nova idéia nobiliárquica, e fundou a aristocracia econômica. $\mathrm{O}$ homem valendo pelo que tem, cada um procura mais ter, construir a sua fortuna, como forma de influir."
\end{abstract}

Durante o transcorrer do Séc. XIX, o mundo passou por significativas transformações sociais, que acabaram por ensejar, paulatinamente, o fenecimento do caráter absoluto conferido à propriedade, pelo ideário da Revolução Francesa.

Com efeito, como observado por Faria (1977, p. 169)

As correntes socialistas investiram de modo violento, contra o direito em análise. A doutrina católica desenvolveu a noção tradicional da 'propriedade humana', subordinando a maior ou menor extensão de tal direito às necessidades fundamentais da pessoa humana (assim, um homem terá direito absoluto a uma casa, onde residirá com a família; o direito a uma segunda moradia não se revestiria da mesma rigidez); desse modo, a propriedade seria proporcional às exigências básicas do ser humano.

Finda a I Guerra Mundial (1914-1918), as constituições, que passaram a ser editadas a partir de então, embora tenham mantido o direito de propriedade, passaram a condicionar o seu uso, ao bem-estar social.

As constituições brasileiras de 1946 (BRASIL, 1946) e de 1988 (BRASIL, 1988) foram elaboradas já sob o predomínio da idéia da função social da propriedade.

De fato, como observa Pereira (1994, p. 33), as constituições brasileiras

[...] foram elaboradas ao tempo em que estas idéias tomavam corpo entre nós, não no sentido de que a propriedade seja socializada pois que um tal conceito contraria as noções mais divulgadas e os princípios seguros consagrados nos códigos de quase todo o mundo, em prol da concepção do domínio como direito subjetivo. 
Anota, ainda, Pereira (1994, p. 33) que,

Sem deixar de ser um direito, com as características de facultas, a propriedade deve ser exercida em sentido social. É o exercício daquele direito que se subordina ao interesse público, e a função social é integrante menos da definição do direito do que ligada ao seu exercício. Toda vez que se esboça um conflito entre o individual e o social, entre o direito de um dono e a conveniência da coletividade, o legislador terá forçosamente de resolvê-lo neste último sentido, ainda que com sacrifício do direito subjetivo. A utilização dos bens apropriáveis estará, pois, na linha de equilíbrio entre a faculdade reconhecida e a conveniência de todos.

Portanto, atualmente, não há como dissociar o exercício do direito de propriedade

de sua função social, com maior razão, em se tratando de recursos ambientais.

Em outras palavras, o exercício do direito de propriedade não pode acontecer sob o predomínio de individualidades.

\subsection{LOTEAMENTO - CONCEITO E GENERALIDADES}

No Brasil, a busca de melhores condições de vida, em especial de ordem econômica, motivou, a partir da década de 50, como observa Custódio (1977), o êxodo de grande parte das pessoas que viviam na zona rural, para as cidades. Estas, por seu turno, não estavam preparadas, em termos habitacionais, para acolhimento de tão grande fluxo migratório.

Considera-se loteamento, segundo Custódio (1977, p. 459),

[...] o processo de divisão de terrenos rurais ou urbanos em lotes destinados à exploração ou à edificação de qualquer natureza, mediante a observância das formalidades legais e regulamentares, visando à saúde, ao bem-estar e à melhoria da vida humana.

Relativamente a loteamento urbano, observa Meirelles (1990, p. 411), que

[...] é a divisão voluntária do solo em unidades edificáveis (lotes), com abertura de vias e logradouros públicos, na forma da legislação pertinente. Distingue-se do desmembramento, que é a simples divisão de área urbana ou urbanizável, com aproveitamento de vias públicas existentes. O loteamento e o desmembramento constituem modalidades do parcelamento do solo, mas apresentam características diversas: o loteamento é meio de urbanização e só se efetiva por procedimento voluntário e formal do proprietário da gleba, que planeja a sua divisão e a submete à 
aprovação da Prefeitura, para subseqüente inscrição no registro imobiliário, transferência gratuita das áreas das vias públicas e espaços livres ao Município e alienação dos lotes aos interessados; o desmembramento é apenas repartição da gleba, sem atos de urbanização, e tanto pode ocorrer pela vontade do proprietário (venda, doação, etc.) como por imposição judicial (arrematação, partilha, etc.), em ambos os casos sem qualquer transferência da área ao domínio público.

A escassez habitacional nas cidades brasileiras, fez com que a propriedade imobiliária valorizasse, segundo Custódio (1977, p. 463)

[...] de forma excessiva, com evidentes repercussões de ordem prática e jurídica. Diante destas circunstâncias, criou-se a 'indústria dos loteamentos de terrenos' nos arredores das cidades, especialmente dos grandes centros urbanos [...]

Ademais, segundo ainda Custódio (1977), como não havia regulamentação específica, os loteamentos ficavam ao sabor das conveniências dos loteadores, que acima de tudo, visavam lucro com o empreendimento, sem, entretanto, em contrapartida, propiciar condições de segurança e saneamento básico aos compradores dos lotes.

Por conta da situação de desamparo experimentada pelos adquirentes de lotes, o governo federal ciente de que o Código Civil de 1916 (BRASIL, 1916), então em vigor, não era suficiente para protegê-los, promulgou em 10 de dezembro de 1937, o Decreto-lei $\mathrm{n}^{\circ} 58$ (BRASIL, 1937), que dispôs sobre o loteamento e venda de terrenos a prestações.

Tal decreto foi regulamentado pelo Decreto $\mathrm{n}^{\mathrm{o}} 3.079$, de 15 de setembro de 1938 (CÓDIGO ..., 2004).

Em 28 de fevereiro de 1967 foi promulgado o Decreto-lei no 271 (BRASIL, 1967c), para que aos loteamentos fossem aplicados os dispositivos da Lei $\mathrm{n}^{\circ} 4.591$, de 16 de dezembro de 1964 (BRASIL, 1964) que dispõe sobre o condomínio em edificações e as incorporações imobiliárias.

Sucede, porém, que na vigência dos Decretos-leis nºs. 58/37 e 271/67, muitos municípios, como observa Meirelles (1990, p. 412),

[...] interpretaram que a matéria era da competência exclusiva da União, e por esse motivo se abstiveram de editar normas urbanísticas locais, passando a aprovar loteamentos sem os requisitos mínimos de habitabilidade, sem áreas livres e sem os 
equipamentos urbanos e comunitários indispensáveis à gleba loteada. O resultado é essa verdadeira 'orgia de loteamentos', que vem provocando uma fictícia valorização imobiliária e um desastroso desordenamento das cidades, tornando improdutivas imensas glebas rurais, convertidas da noite para o dia em terrenos urbanos, desservidos de qualquer melhoramento público e sem condições de habitabilidade, os quais irão exigir, mais tarde, a execução desses equipamentos pela própria Prefeitura.

Em 19 de dezembro de 1979, foi promulgada a Lei Federal $n^{\circ} 6.766$ (BRASIL,

1979), que dispõe sobre o parcelamento do solo urbano e estabelece regras gerais, de cunho urbanístico, para os loteamentos.

Tais regras fixam padrões mínimos de urbanização para a área a ser loteada, bem como para as condições de habitabilidade dos lotes ou terrenos.

Outrossim, o legislador, com o intuito de reparar os equívocos acima especificados, surgidos na vigência dos Decretos-leis nºs. 58/37 (BRASIL, 1937) e 271/67 (BRASIL, 1967c), assegurou no parágrafo único, do art. $1^{\circ}$, a possibilidade dos Estados, Distrito Federal e dos Municípios estabelecerem normas complementares relativas ao parcelamento do solo municipal, para adequar o previsto na Lei $n^{\circ} 6.766 / 79$, às peculiaridades regionais e locais.

Necessário destacar que o loteamento, segundo magistério de Meirelles (1990, p. 412),

[...] sujeita-se a cláusulas convencionais e a normas legais de duas ordens: civis e urbanísticas. As cláusulas convencionais são as que constarem do memorial arquivado no registro imobiliário, para transcrição nas escrituras de alienação dos lotes; as normas civis são expressas na legislação federal pertinente e visam a garantir aos adquirentes de lotes a legitimidade da propriedade e a transferência do domínio ao término do pagamento do preço; as normas urbanísticas são as constantes da legislação municipal e objetivam assegurar ao loteamento os equipamentos e condições mínimas de habitabilidade e conforto, bem como harmonizá-lo com o plano diretor do Município, para a correta expansão de sua área urbana. Por isso, tratando-se de propriedade urbana, o projeto e a planta do loteamento devem ser previamente aprovados pela Prefeitura, ouvidas, quanto ao que lhes disser respeito, as autoridades sanitárias (estaduais), militares e, quando incidir sobre área total ou parcialmente florestada, as autoridades florestais [...]

Os loteamentos uma vez aprovados pelas prefeituras municipais, devem ser registrados nos cartórios de registro imobiliário. 


\title{
8 ANÁlise do PROCESSO DE REGISTRO DO LOTEAMENTO POPULAR CIDADE ARACY
}

O loteamento denominado Cidade Aracy está localizado na zona sul da área urbana do município de São Carlos e é de propriedade da loteadora Agropecuária e Administração de Bens Cidade Aracy SC Ltda. Foi aprovado pela Prefeitura Municipal de São Carlos em 28 de setembro de 1983, nos autos do processo administrativo n $^{\circ}$ 4392/1982 (SÃO PAULO (Estado). Cartório de Registro de Imóveis e Anexos, 1984).

Em obediência ao que dispõe o art. 18, da Lei nº 6.766/79 (BRASIL, 1979), o pedido de registro do loteamento foi protocolado no Registro de Imóveis de São Carlos, em 22 de fevereiro de 1984.

Em histórico feito pelo Ministério Público do Estado de São Paulo, quando da elaboração de Termo de Compromisso de Ajustamento de Conduta firmado entre o Ministério Público, a Loteadora e o Município de São Carlos, inserido no processo de registro do loteamento (SÃO PAULO (Estado). Cartório de Registro de Imóveis e Anexos, 1984, p. 553), consta que

\begin{abstract}
A empresa loteadora, em vista do porte do loteamento, implantou-o em etapas, executando algumas obras de infra-estrutura, tais como abertura de vias públicas, redes de água e esgoto e energia elétrica, promovendo a venda dos lotes por meio de Contrato de Compromisso de Compra e Venda, que na sua grande maioria não foram submetidos a registros. [...] Grande parte das obras de infra-estrutura constantes dos contratos de compra e venda, foram executadas pela empresa loteadora, outras pela Prefeitura Municipal.
\end{abstract}

Consigne-se que o loteamento, segundo o que consta dos autos do processo de registro (SÃO PAULO (Estado). Cartório de Registro de Imóveis e Anexos, 1984), foi implantado sem observância do projeto aprovado. 


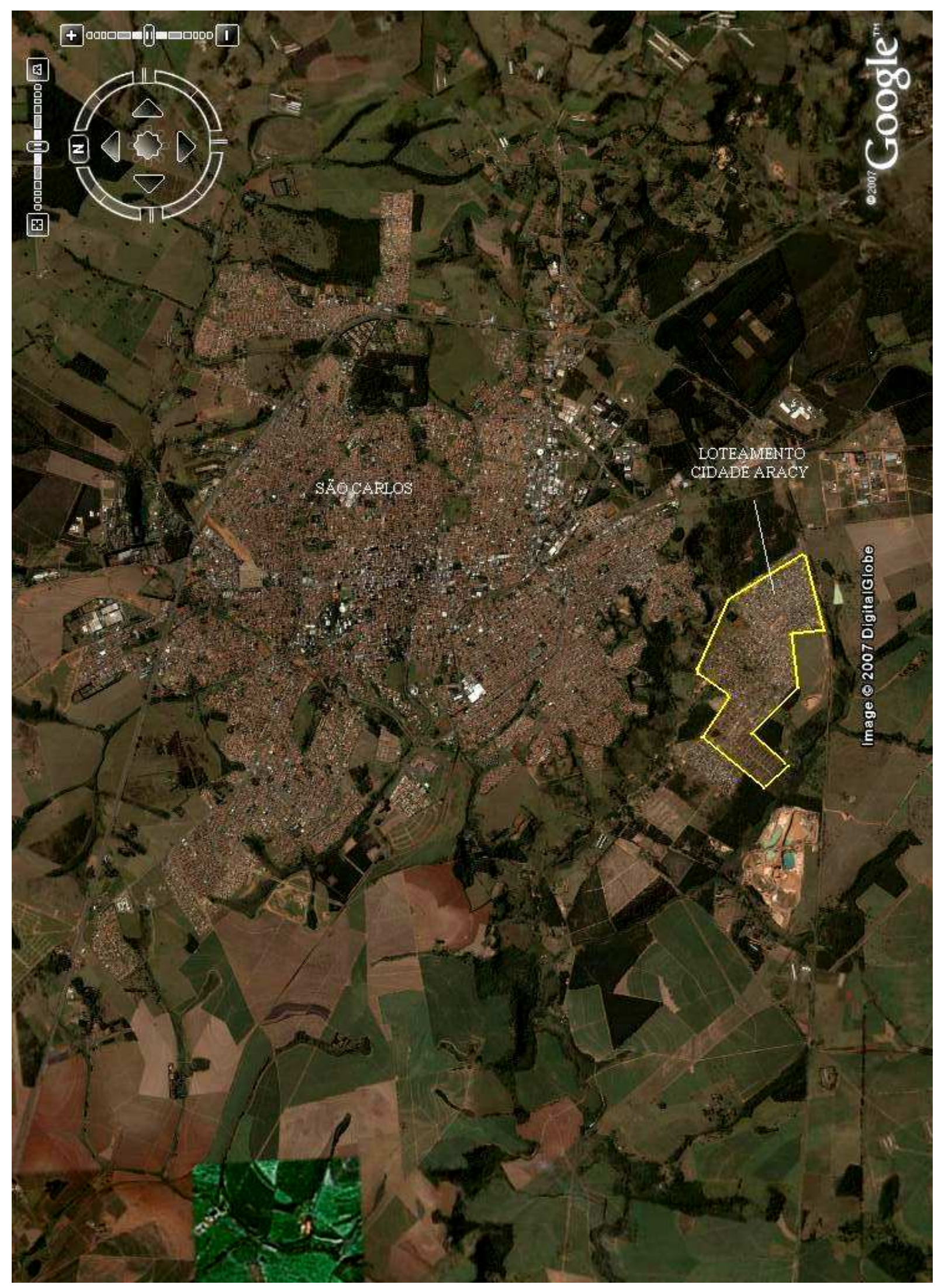

Ilustração 4: Vista aérea da Cidade de São Carlos, com destaque ao Loteamento Cidade Aracy Fonte: Google earth (2007) 
As ruas acabaram por ser prolongadas e as áreas reservadas para sistema de lazer, inclusive áreas verdes, foram transformadas em vias públicas.

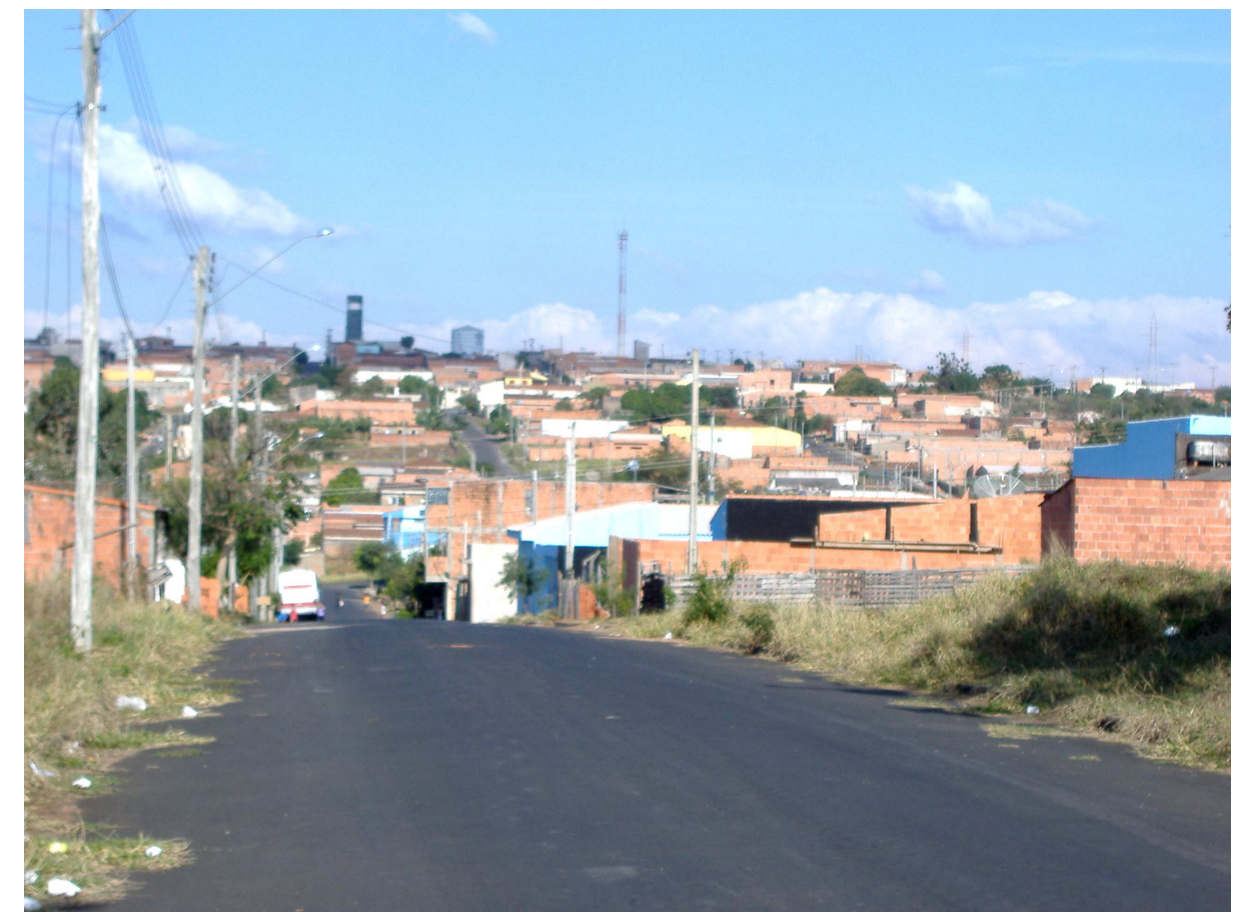

Ilustração 5: Vista parcial do Loteamento Fonte: Lemmi (2007)

Em 16 de dezembro de 2003, quando da celebração de Termo de Compromisso de Ajustamento de Conduta firmado entre o Ministério Público do Estado de São Paulo; Prefeitura Municipal de São Carlos e Loteadora, inserido a fls. 550/558, dos autos do processo de registro de loteamento, as obras de infra-estrutura do loteamento não estavam concluídas, não obstante já tivessem decorrido mais de 20 anos da data em que o loteamento havia sido aprovado pela Prefeitura do Município de São Carlos.

Como efeito, consta do Termo de Ajustamento e Conduta que em 2003, ainda restavam para execução, obras de galerias de águas pluviais, guias e sarjetas e pavimentação asfáltica.

Paralelamente, as obras já executadas apresentam problemas, inclusive de ordem ambiental, merecendo ênfase aqueles decorrentes da erosão e assoreamento dos cursos d'água 
(Córrego Água Quente e Córrego Água Fria), que passam pelo local, como demonstram as ilustrações que seguem:

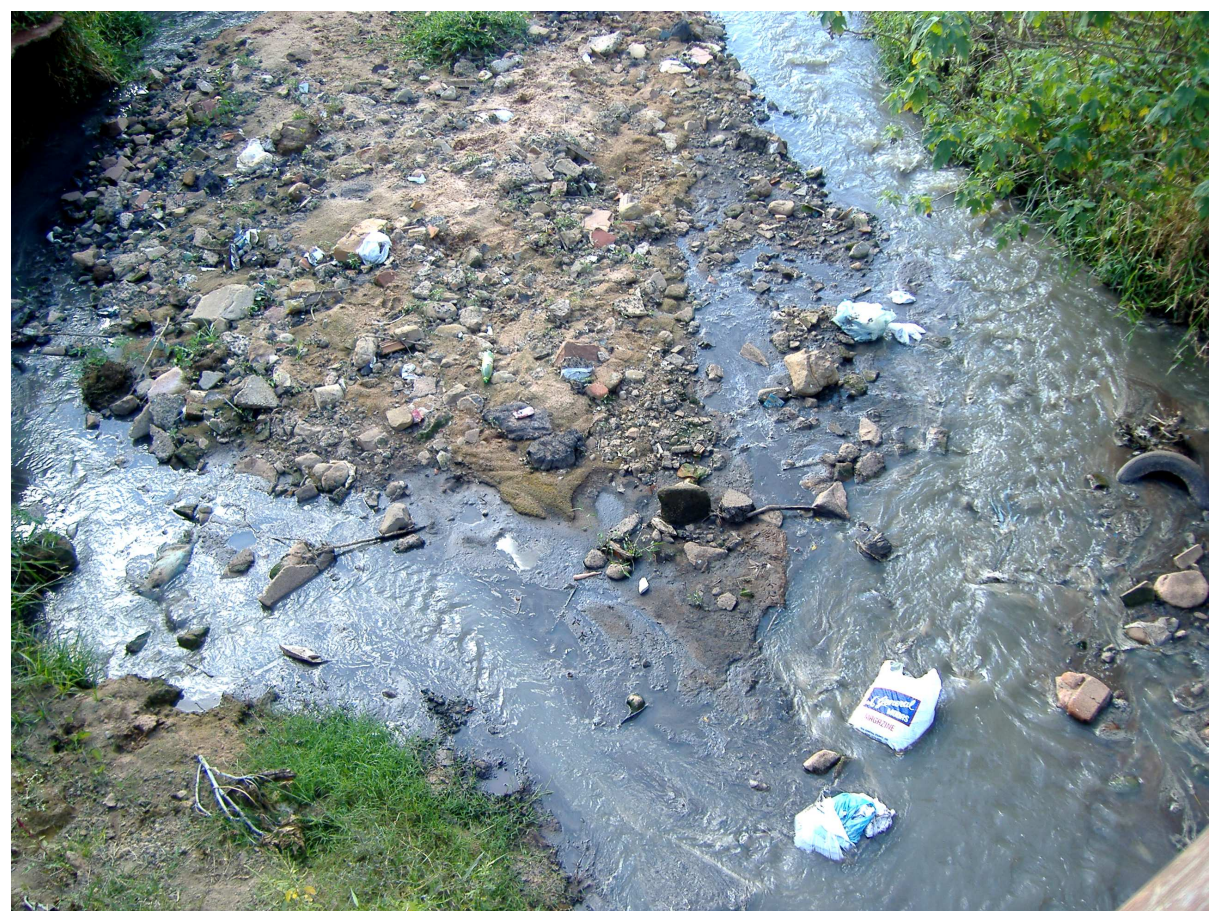

Ilustração 6: Córrego da Água Quente

Fonte: Lemmi (2007)

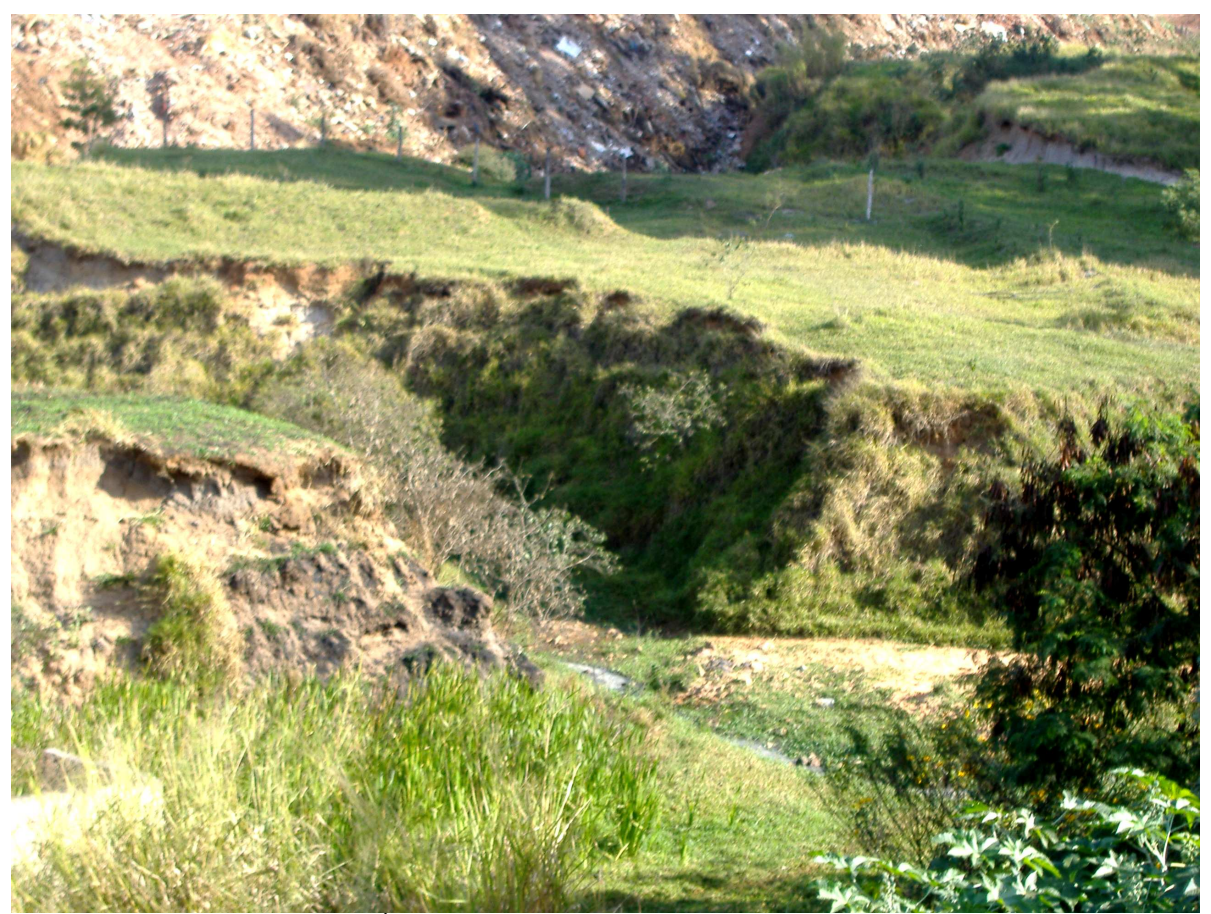

Ilustração 7: Córrego da Água Quente

Fonte: Lemmi (2007) 


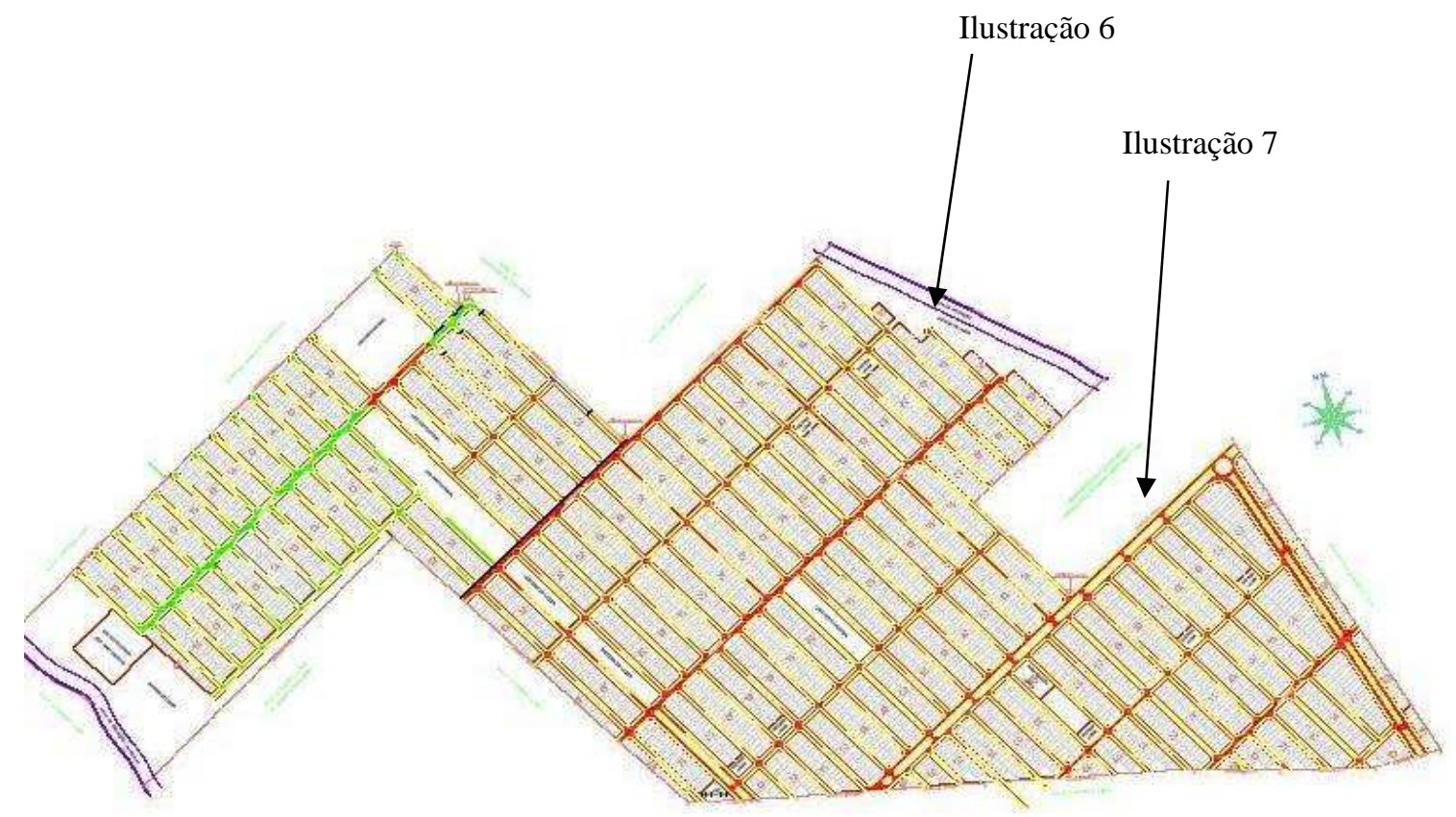

Ilustração 8: Mapa do loteamento Cidade Aracy

Fonte: Prefeitura Municipal de São Carlos (2004) 


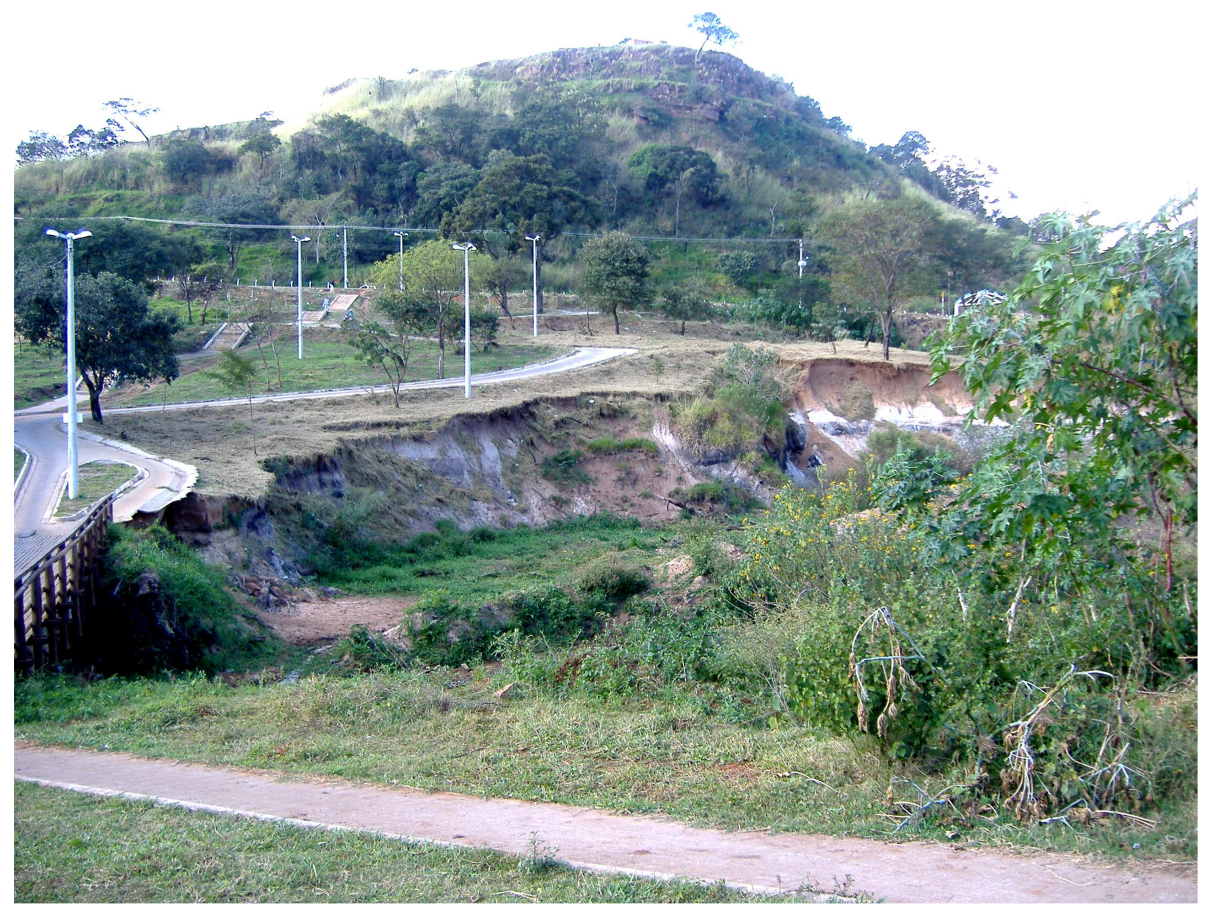

Ilustração 9: Acesso para pedestres - vista da erosão - Cidade Aracy II Fonte: Lemmi (2007)

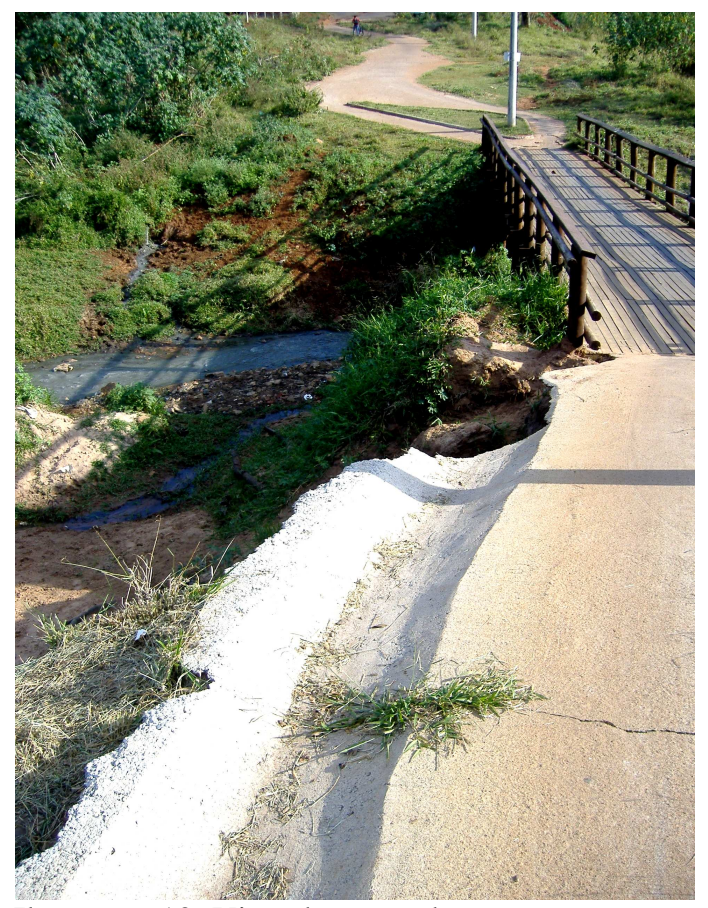

Ilustração 10: Vista da ponte do acesso para pedestres sobre o Córrego da Água Quente Fonte: Lemmi (2007) 


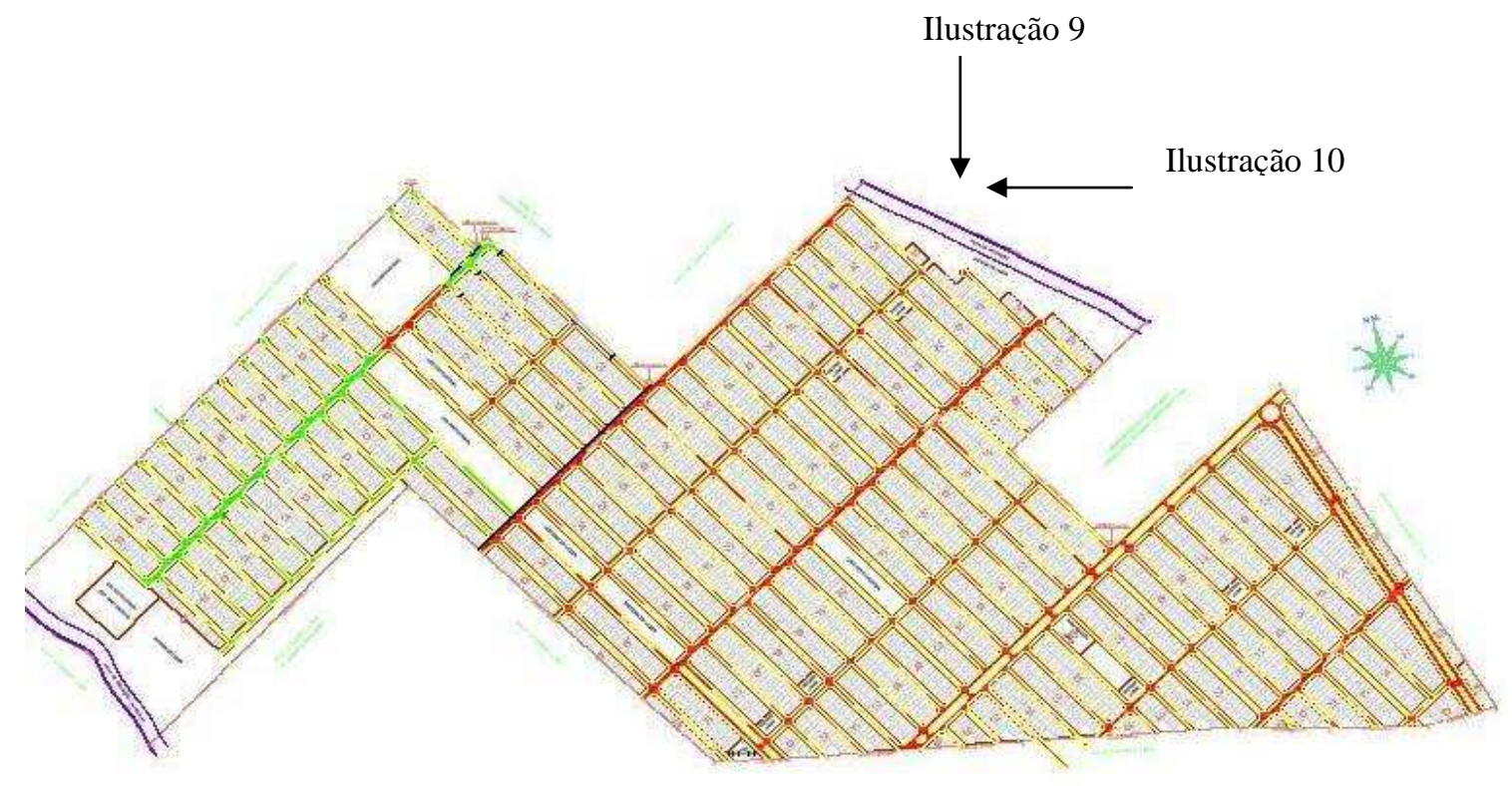

Ilustração 11: Mapa do loteamento Cidade Aracy

Fonte: Prefeitura Municipal de São Carlos (2004) 


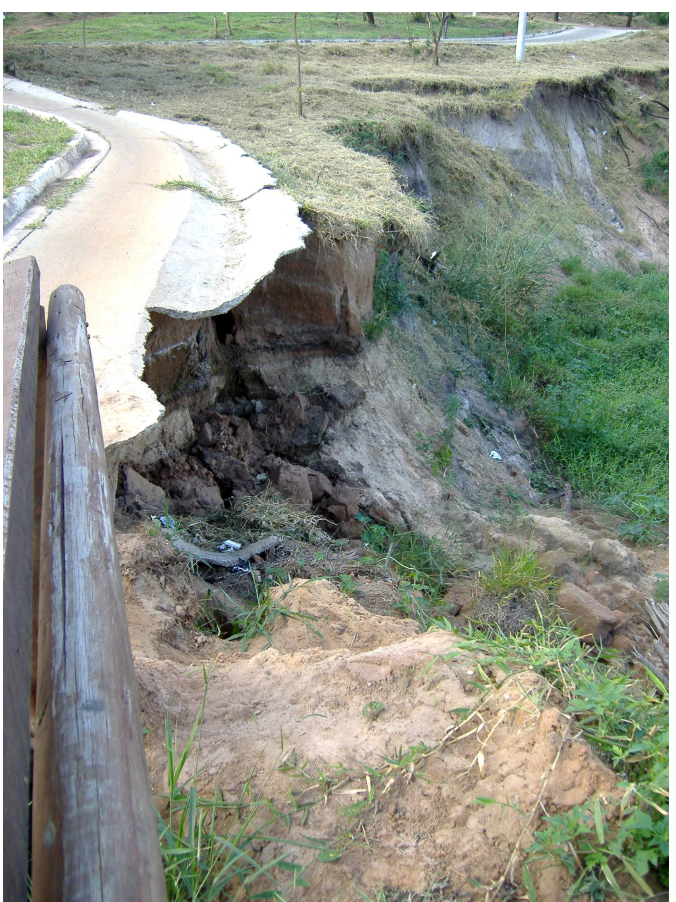

Ilustração 12: Erosão sob a ponte de acesso para pedestres

Fonte: Lemmi (2007)

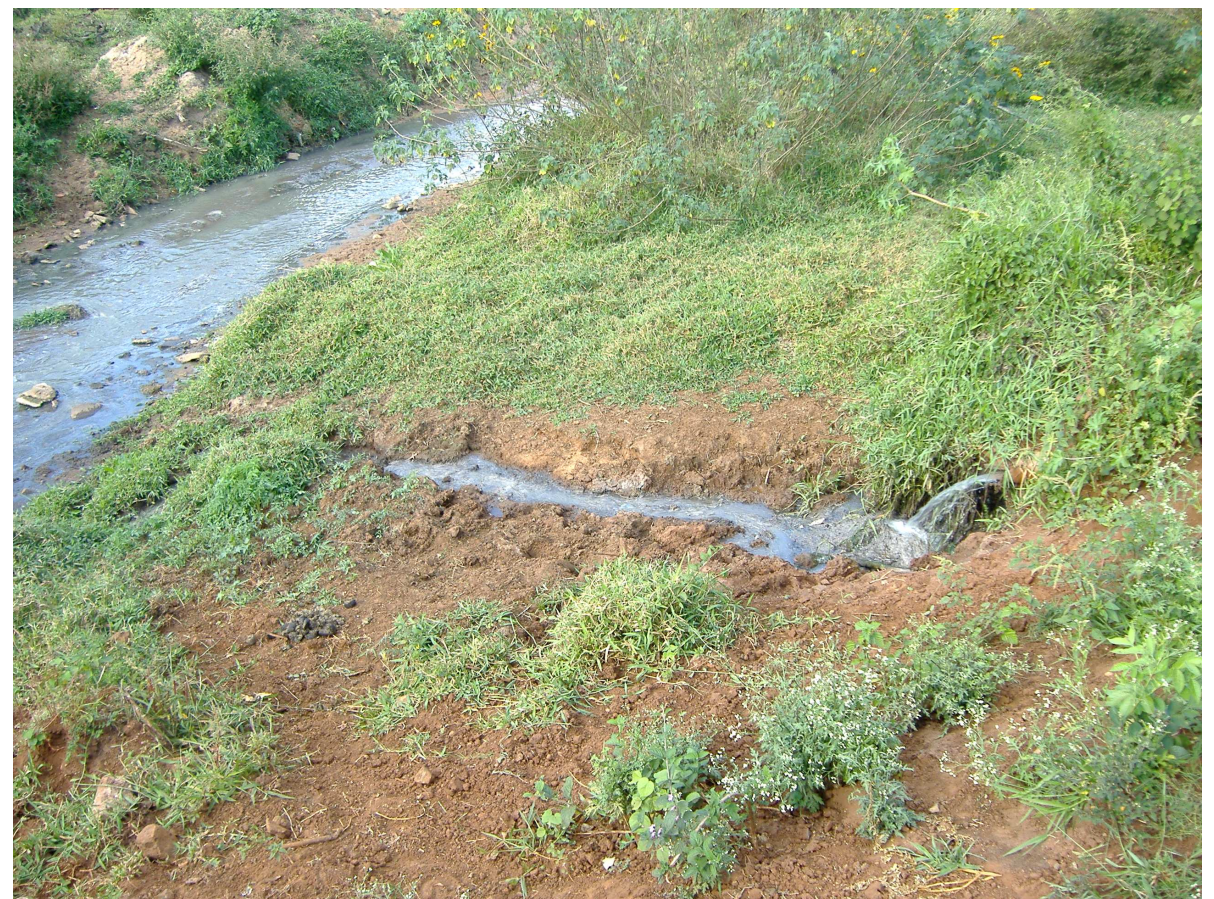

Ilustração 13: Emissão de esgoto, sem tratamento, no Córrego da Água Quente Fonte: Lemmi (2007) 


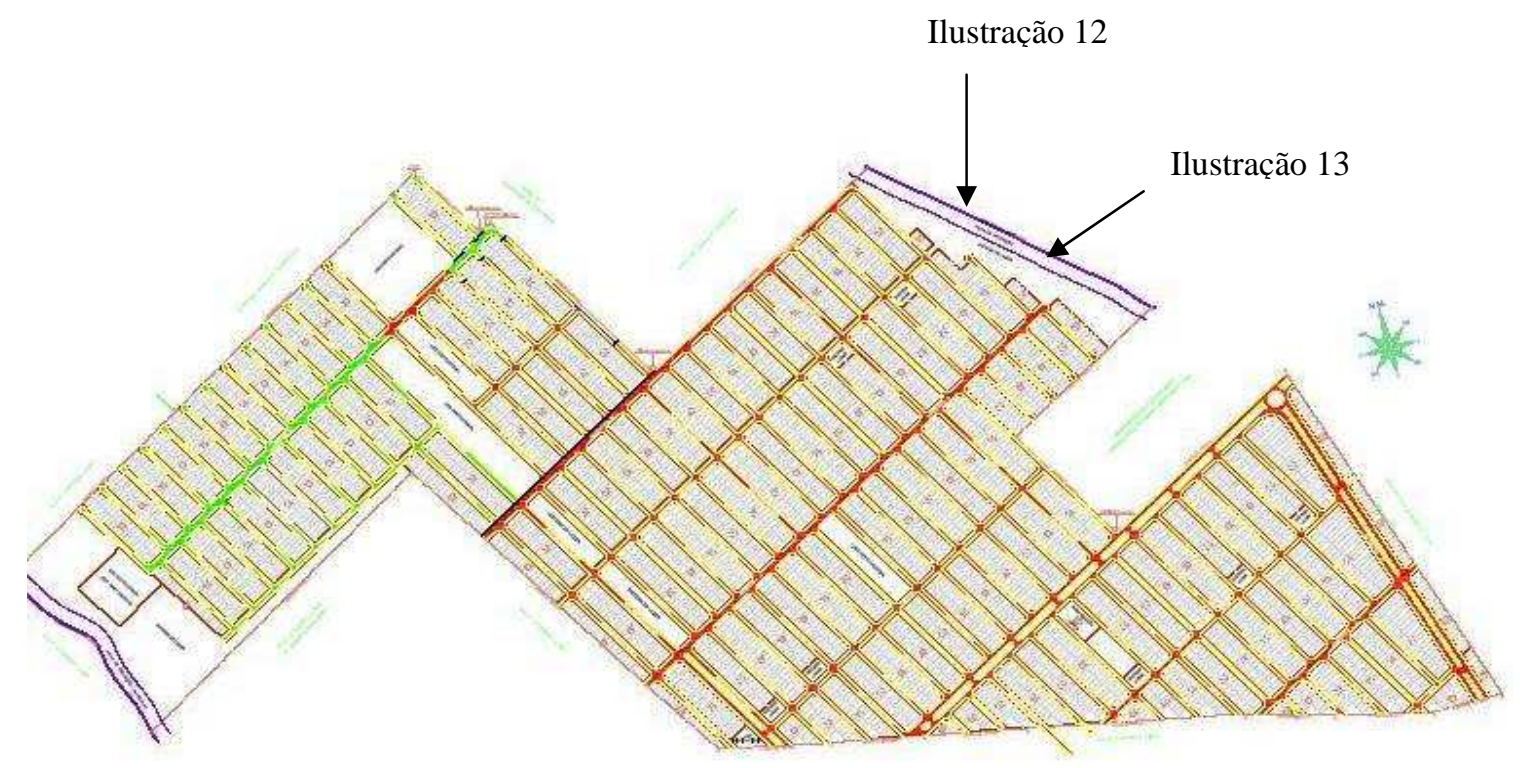

Ilustração 14: Mapa do loteamento Cidade Aracy

Fonte: Prefeitura Municipal de São Carlos (2004) 


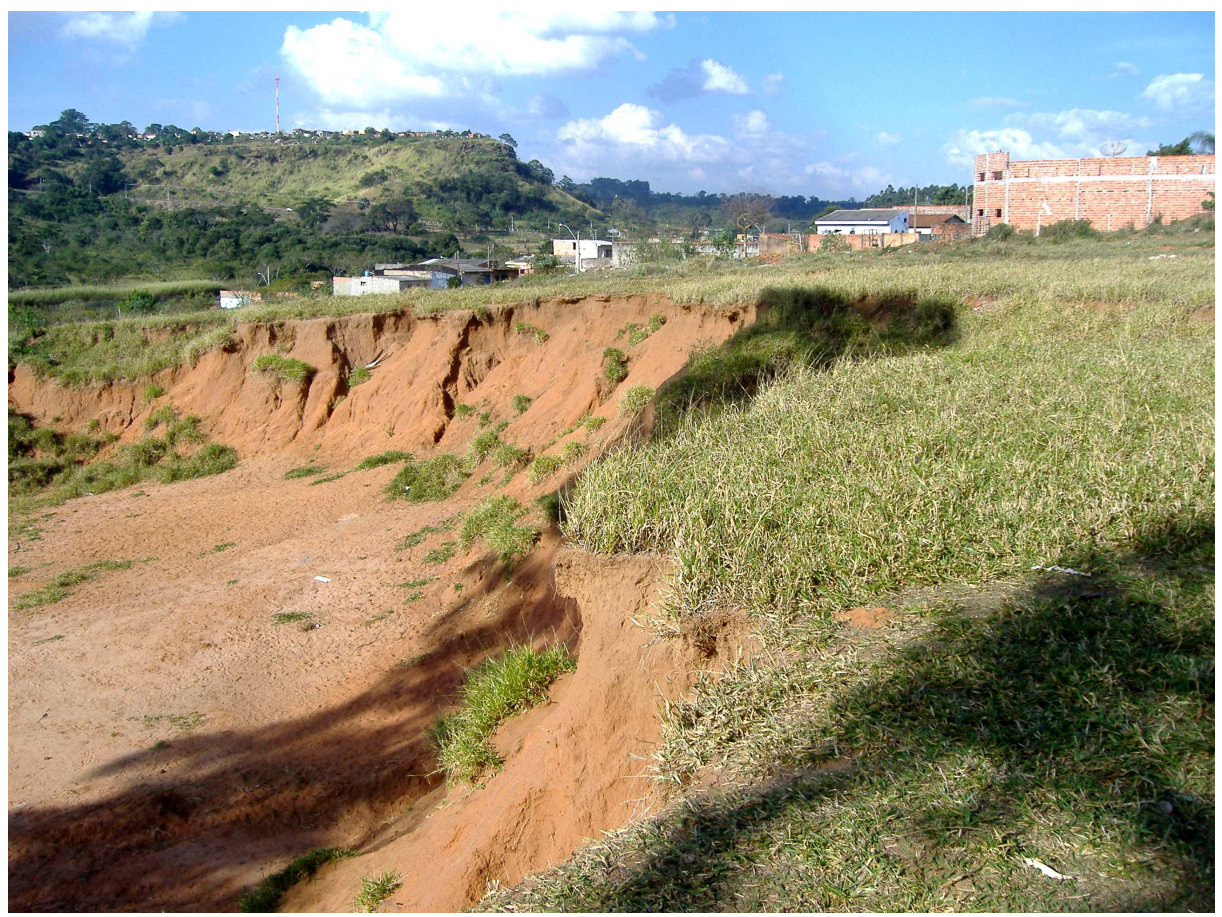

Ilustração 15: Vista da erosão localizada nas proximidades da Av. Arnoldo de Almeida Pires

Fonte: Lemmi (2007)

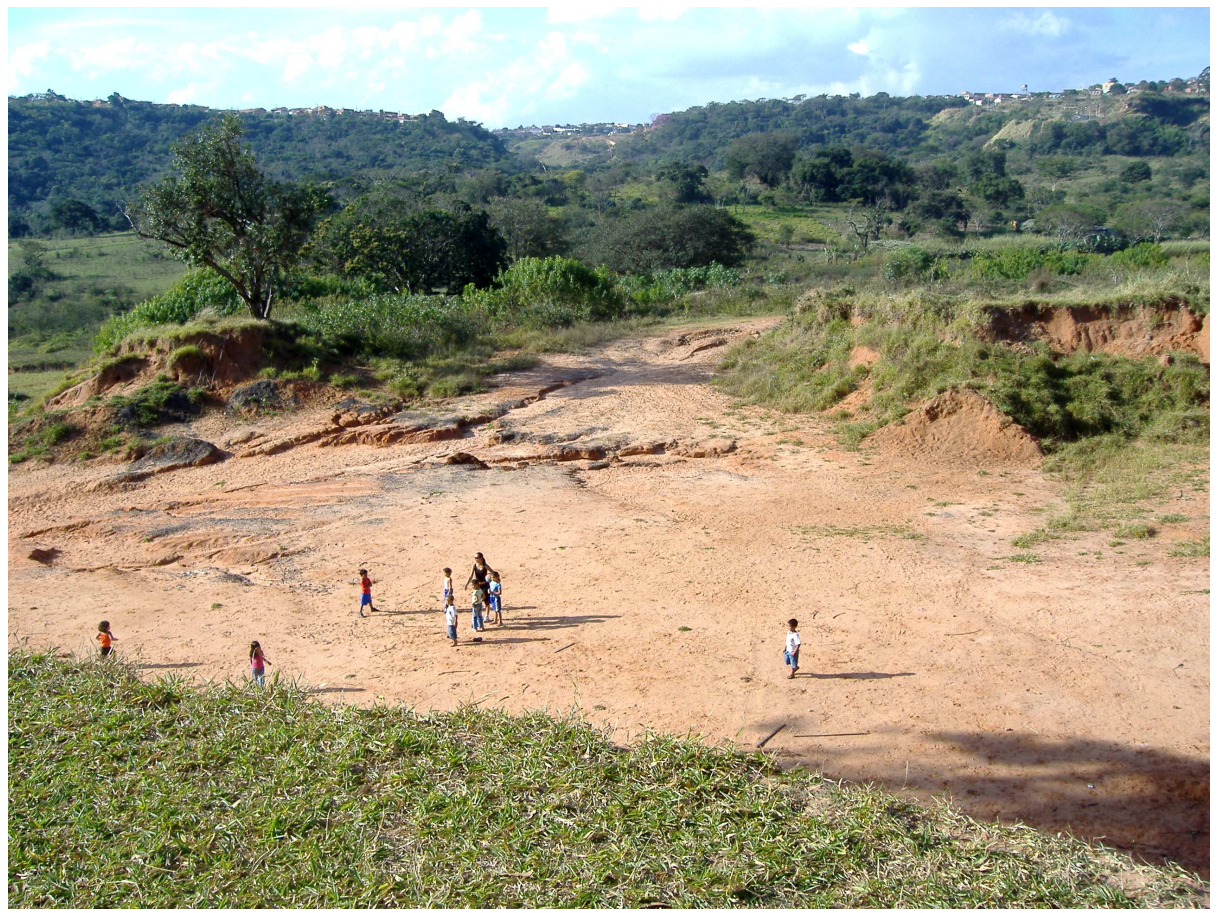

Ilustração 16: Vista da erosão localizada nas proximidades da Avenida Av. Arnoldo de Almeida Pires (outro ângulo)

Fonte: Lemmi (2007) 


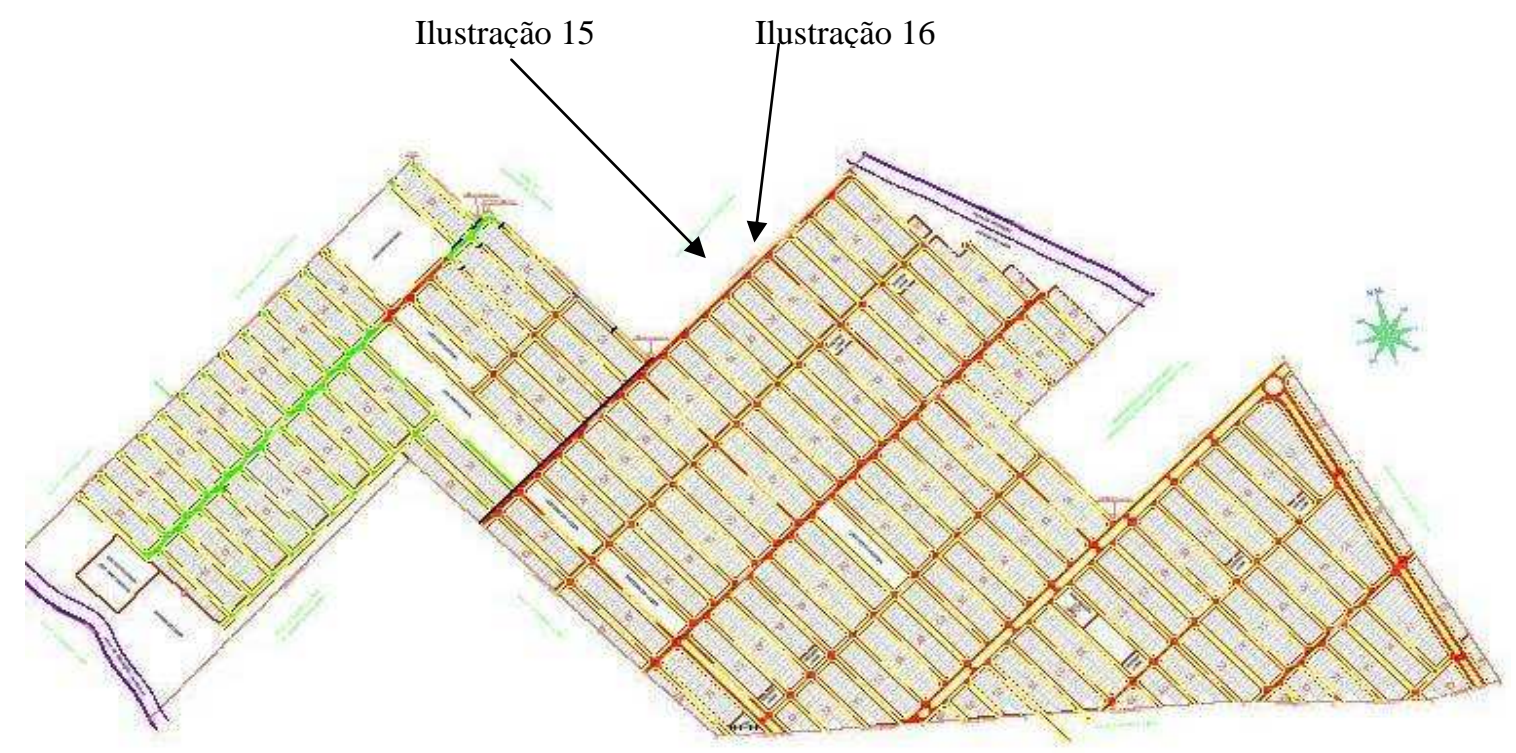

Ilustração 17: Mapa do loteamento Cidade Aracy

Fonte: Prefeitura Municipal de São Carlos (2004) 


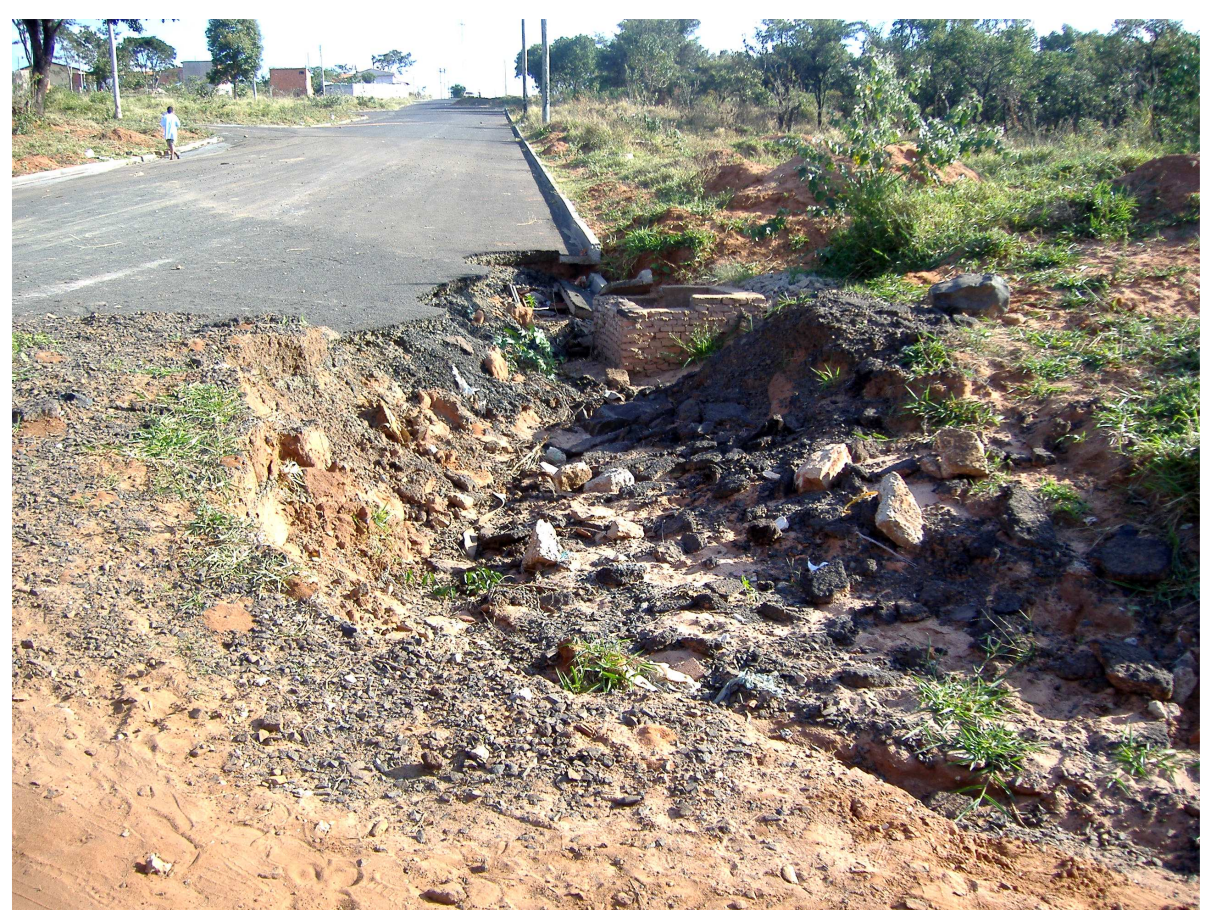

Ilustração 18: Erosão incidente sobre o asfalto em razão das chuvas

Fonte: Lemmi (2007)

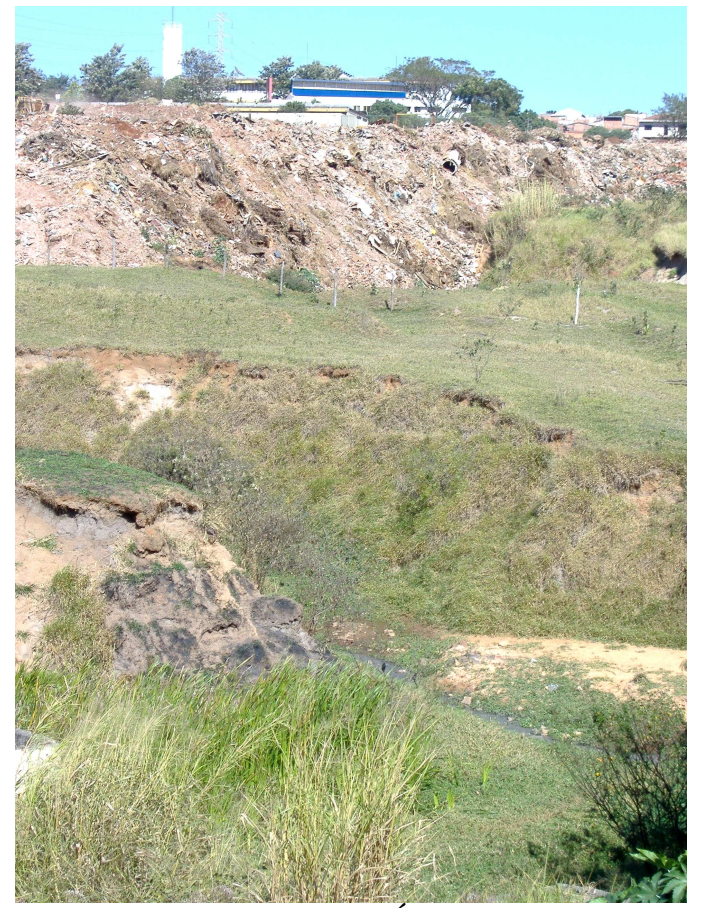

Ilustração 19: Córrego da Água Quente.

Ao fundo, aterro da erosão com utilização de entulho de construção civil

Fonte: Lemmi (2007) 


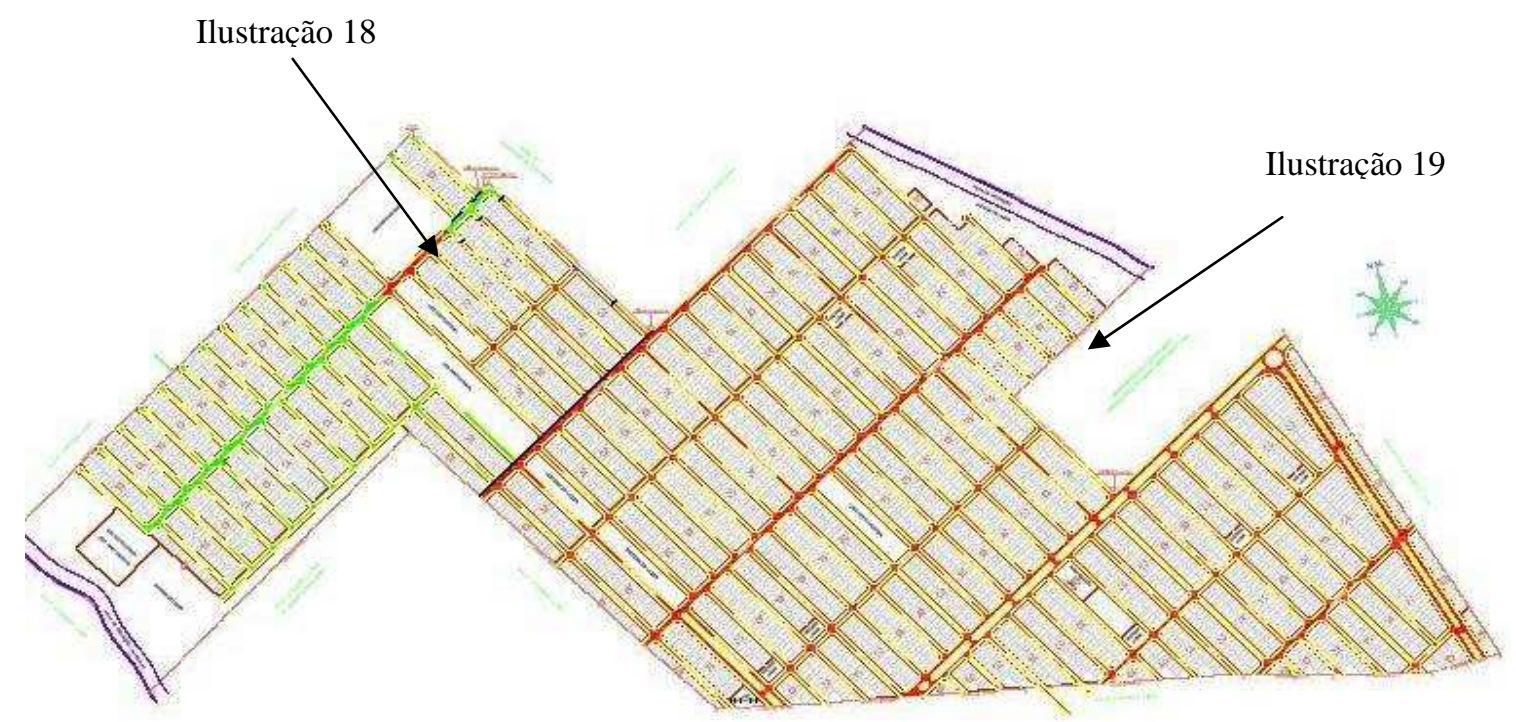

Ilustração 20: Mapa do loteamento Cidade Aracy

Fonte: Prefeitura Municipal de São Carlos (2004) 
Segundo Pedro e Lorandi (2004), a implantação desordenada de loteamentos no município de São Carlos, dentre eles, o loteamento Cidade Aracy, é que ensejou sérios problemas decorrentes da erosão urbana.

Com efeito, "na região de São Carlos os solos mais susceptíveis à erosão (Litólicos e Areia Quartzosa) estão localizados ao sul da área urbana" (PEDRO; LORANDI, 2004, p. 31), exatamente onde foi implantado o loteamento Cidade Aracy.

Como acima observado, a Lei Federal n 6.938/81 (BRASIL, 1981), que dispôs sobre a Política Nacional do Meio Ambiente, criou os instrumentos da Avaliação de Impacto Ambiental (AIA) e o Zoneamento Ambiental, que, uma vez corretamente aplicados, podem contribuir para a conciliação do desenvolvimento sócio-econômico com preservação ambiental.

Quando da implantação do loteamento Cidade Aracy, já se encontravam em vigor, a Lei Federal no 6.938/81 (BRASIL, 1981) e a Lei Estadual nº 997, de 31 de maio de 1976 (SÃO PAULO, 1976a), regulamentada pelo Decreto $n^{\circ}$ 8.468, de 08 de setembro de 1976 (SÃO PAULO, 1976b).

O Decreto $n^{\circ}$ 8.468/76 (SÃO PAULO, 1976b), conferiu à Cetesb - Companhia Estadual de Tecnologia de Saneamento Básico e de Defesa do Meio Ambiente, atribuições para controle e preservação do meio ambiente.

Também em vigor já se encontrava a Lei Federal nº 6.766/79 (BRASIL, 1979), cujo art. $1^{\circ}$, parágrafo único, assegurou a possibilidade dos Municípios estabelecerem normas complementares relativas ao parcelamento do solo municipal, para adequar o previsto naquele normativo, às peculiaridades regionais e locais.

Portanto, o Poder Público já dispunha, na época da implantação do loteamento, de instrumentos legais aptos a detectarem e minimizarem problemas ambientais e, via de 
consequiência, problemas sócio-econômicos, como aqueles verificados no Loteamento Cidade Aracy.

De fato, se a Avaliação de Impacto Ambiental pode ser vista, segundo Sanchez (1995, p. 13), "[...] como um instrumento de prevenção do dano ambiental [...]", afigura-se claro que tivesse a implantação do loteamento sido precedida da aplicação do conjunto de procedimentos que o processo da AIA abrange, os impactos ambientais que a ação humana acabou por causar no local, poderiam ter sido previstos e minimizados.

Já a utilização do Zoneamento Ambiental teria dado condições ao Município de verificar as possibilidades de efetivo uso antrópico da área em que implantado o loteamento.

Com efeito, por conta de cenários previamente montados, o Poder Público teria noção das fragilidades do solo da região do empreendimento e, consequentemente, ciente da possibilidade da ocorrência de processos erosivos e de situações de assoreamento, teria como orientar sua ação, no que tange à eficácia e dimensão das obras de infra-estrutura, quando do pedido de aprovação do loteamento, conforme analisado por Montaño (2002). 


\section{CONCLUSÕES}

Embora a legislação brasileira seja considerada apta à garantia de sustentabilidade ambiental, como observa Nalini (2001), sua vivência ou aplicação, mostra resultados bem diversos daqueles que eram esperados pelo legislador, pois, diversos setores da sociedade, ainda adotam postura que Garrard (2006, p. 32-33), denomina de "cornucopiana", para a qual

[...] o dinamismo das economias capitalistas gerará soluções para os problemas ambientais à medida que eles surgirem, assim, como os aumentos populacionais acabarão produzindo a riqueza necessária para bancar o custo das melhorias do meio ambiente.

O histórico extrativista brasileiro e a depleção de recursos naturais decorrente do ideário de infinitude destes, que sempre permeou a sociedade brasileira, demonstram que o meio ambiente, durante muito tempo, não integrou a pauta de preocupações da política sócioeconômica e quando o fez, foi de forma periférica, tendo por objeto a proteção de interesses outros, que não a preservação ambiental e dos recursos naturais.

Não obstante o esforço de diversos setores formadores de opinião pública, tais como as universidades, parte do Poder Legislativo, Ministério Público, Poder Judiciário, organizações não-governamentais, a visão utilitária do meio ambiente continua, tal como foi ao longo de nossa história, bem presente entre nós.

Uma parcela da sociedade brasileira, por conta de sucessivas crises econômicas, continua envolvida com a satisfação de suas necessidades primárias básicas e, conseqüentemente, ainda, alheia à idéia de preservação ambiental e escassez de recursos naturais.

Em matéria ambiental continua a haver, tal como observado por Holanda (2006), o predomínio de vontades particulares, pouco dispostas à observância da legislação vigente, que tem cunho impessoal. 
Grande parte da sociedade brasileira ainda não assimilou o meio ambiente como valor, por conta da idéia de que a legislação ambiental se constitui um entrave ao desenvolvimento do país posto que os perigos decorrentes de impactos ambientais causados pela destinação inadequada dos resíduos sólidos; pela poluição do ar; pela má gestão de recursos hídricos, ou pelo loteamento inadequado de espaços urbanos, são considerados ilusórios ou exagerados.

A expressão ou vivência perene pela sociedade do valor meio ambiente, protegido pela Constituição Federal (art. 225) (BRASIL, 1988), bem como a conscientização da necessidade da preservação ambiental, se constituem condição a ser alcançada pelos brasileiros e não realidade, posto que ainda não assimilada por todos os setores decisórios da sociedade, a noção de que o sistema econômico não está acima do ecossistema, mas, sim, depende dele, que é fonte supridora de recursos, aptos a serem transformados em ganho de capital.

As dificuldades apresentadas pelo Loteamento Cidade Aracy não só demonstram a manutenção do predomínio de vontades particulares, indiferentes à lei geral, tal como descrito por Holanda (2006) mas, também, dão conta de que a atuação do Poder Público no tema, vem se limitando, não de forma exatamente bem sucedida, a controlar corretivamente danos decorrentes de impactos ambientais previsíveis e consequentemente evitáveis, caso tivessem sido utilizados na ocasião adequada, os instrumentos de política e gestão ambiental (Zoneamento e AIA) previstos na lei de política ambiental (Lei nº 6938/81) (BRASIL, 1981).

Não obstante dispusesse do princípio do poluidor pagador para orientar sua atividade no loteamento, o Poder Público não logrou impor ao loteador de forma efetiva, os custos decorrentes dos danos ambientais que o empreendimento, na forma como implementado, acabou por provocar. 
Tampouco, por falta de informação adequada, foi assegurada à coletividade, a possibilidade de manifestação e participação, quando da implantação do loteamento e quando da execução das obras feitas no local.

A erosão e o assoreamento, continuam presentes e as obras executadas são meramente paliativas, como ilustram as fotografias inseridas neste trabalho.

A assimilação pela sociedade do valor meio ambiente depende da difusão, nas mais variadas formas, tais como encontros, publicações, campanhas ambientalistas, de que a proteção do ecossistema exige a participação de toda a sociedade e não apenas da atuação do Poder Público.

A divulgação do histórico extrativista brasileiro e dos equívocos decorrentes da idéia de infinitude dos recursos naturais, pode ajudar a modificar o modo de pensar, pois, uma vez bem informada, a sociedade terá condições de romper o circulo vicioso por ela vivido, em matéria ambiental, desde a colonização, e criar nova realidade.

A preservação ambiental não pode ser objeto da pauta de preocupações de alguns, mas, sim, deve se constituir desafio constante a permear a consciência de todos. 


\section{REFERÊNCIAS}

ABBAGNANO, N. (1970). Dicionário de filosofia. Tradução de Alfredo Bosi. São Paulo: Mestre Jou.

ALLENDE, I. (2005). Um sopro de esperança. In: GALEANO, E. (2005). As Veias abertas da América Latina. Prefácio de Isabel Allende. 45. ed. São Paulo: Paz e Terra. p. 7-12.

BRASIL (1916). Lei no 3.071, de 01 de janeiro de 1916. Código Civil. Disponível em: <http://www.planalto.gov.br/ccivil_03/Leis/L3071.htm>. Acesso em: 6 jan. 2007.

BRASIL (1934). Decreto $\mathbf{n}^{\mathbf{0}} \mathbf{2 3 . 7 9 3}$, de 23 de janeiro de 1934. Aprova o código florestal que com este baixa. Disponível em: <http://www.planalto.gov.br/ccivil_03/decreto/19301949/D23793.htm>. Acesso em: 16 mar. 2007.

BRASIL (1937). Decreto-lei $\mathbf{n}^{0}$ 58, de 10 de dezembro de 1937. Dispõe sobre o loteamento e a venda de terrenos para pagamento em prestações. Disponível em: <https://www.planalto.gov.br/ccivil_03/decreto-lei/1937-1946/Del058.htm>. Acesso em: 16 mar. 2007.

BRASIL (1964). Lei $\mathbf{n}^{\mathbf{0}}$ 4.591, de 16 de dezembro de 1964. Dispõe sobre o condomínio em edificações e as incorporações imobiliárias. Disponível em:

<http://www.planalto.gov.br/ccivil_03/Leis/L4591.htm>. Acesso em: 12 jan. 2007.

BRASIL (1965). Lei $\mathbf{n}^{\mathbf{0}}$ 4.771, de 15 de setembro de 1965. Institui o novo código florestal. Disponível em: <http://www.planalto.gov.br/ccivil_03/Leis/L4771.htm>. Acesso em: 22 maio 2007.

BRASIL (1967a). Lei no 5.197, de 03 de janeiro de 1967. Dispõe sobre a proteção à fauna e dá outras providências. Disponível em: <http://www.planalto.gov.br/ccivil_03/Leis/L5197.htm>. Acesso em: 28 abr. 2007.

BRASIL (1967b). Decreto-Lei no 221, de 28 de fevereiro de 1967. Dispõe sobre a proteção e estímulos à pesca e dá outras providências. Disponível em:

<http://www.planalto.gov.br/ccivil_03/Decreto-Lei/Del0221.htm>. Acesso em: 28 abr. 2007.

BRASIL (1967c). Decreto-lei $\mathbf{n}^{\mathbf{0}}$ 271, de 28 de fevereiro de 1967. Dispõe sobre loteamento urbano, responsabilidade do loteador, concessão de uso e espaço aéreo e dá outras providências. Disponível em: <https://www.planalto.gov.br/ccivil_03/decretolei/Del0271.htm>. Acesso em: 12 jan. 2007.

BRASIL (1975). Decreto-Lei $\mathbf{n}^{\circ} \mathbf{1 . 4 1 3}$, de 14 de agosto de 1975. Dispõe sobre o controle da poluição do meio ambiente provocada por atividades industriais. Disponível em:

<http://www.prpe.mpf.gov.br/internet/content/view/full/515>. Acesso em: 28 abr. 2007.

BRASIL (1979). Lei $\mathbf{n}^{\mathbf{0}}$ 6.766, de 19 de dezembro de 1979. Dispõe sobre o parcelamento do Solo Urbano e dá outras providências. Disponível em:

<http://www.planalto.gov.br/ccivil_03/Leis/L6766.htm>. Acesso em: 12 jan. 2007. 
BRASIL (1981). Lei $\mathbf{n}^{\circ}$ 6.938, de 31 de agosto de 1981. Dispõe sobre a Política Nacional do Meio ambiente, seus fins e mecanismos de formulação e aplicação, e dá outras providências. Disponível em: <http://www.planalto.gov.br/ccivil_03/Leis/L6938.htm>. Acesso em: 12 jan. 2007.

BRASIL (1989). Lei $\mathbf{n}^{\mathbf{0}} \mathbf{7 . 7 3 5}$, de 22 de fevereiro de 1989. Dispõe sobre a extinção de órgão e de entidade autárquica, cria o Instituto Brasileiro do Meio Ambiente e dos Recursos Naturais Renováveis e dá outras providências. Disponível em:

<http://www.planalto.gov.br/ccivil_03/Leis/QUADRO/1989.htm>. Acesso em: 12 jan. 2007.

BRASIL. Constituição (1946). Constituição dos Estados Unidos do Brasil. Brasília. DF: Senado. Disponível em:

<http://www.planalto.gov.br/ccivil_03/Constituicao/Constituiçao46.htm>. Acesso em: 12 jan. 2007.

BRASIL. Constituição (1988). Constituição da República Federativa do Brasil. Brasília, DF: Senado.

CANOTILHO, J. J. G. (Coord.). (1998). Introdução ao direito do ambiente. Lisboa: Universidade Aberta.

CAVALCANTI, C. (1996). Desenvolvimento e respeito à natureza: uma introdução termodinâmica à economia da sustentabilidade. In: FERREIRA, L. C.; VIOLA, E. (Org.). Incertezas de sustentabilidade na globalização. Campinas: Ed. UNICAMP. p. 319-329.

CÓDIGO Civil, atualizado até 6 jan. 2004. (2004). 9. ed. rev. atual. e amp. São Paulo: Revista dos Tribunais. p. 804-811.

CUSTÓDIO, H. B. (1977). Loteamento. In: FRANÇA, R. L. Enciclopédia saraiva do direito. São Paulo: Saraiva. v.50, p.459-483.

DAMATTA, R. (2007). Adultério à brasileira: o papel da novela. O Estado de São Paulo, São Paulo, p. d 14, 9 maio.

DIAMOND, J. (2005). Colapso: como as sociedades escolhem o fracasso ou o sucesso. Tradução de Alexandre Raposo. 2. ed. Rio de Janeiro: Record.

DINAMARCO, C. R. (1988). O poder judiciário e o meio ambiente. Revista dos Tribunais, São Paulo, v. 631, p. 24-28.

FARIA, A. O. (1977). Propriedade II. In: FRANÇA, R. L. Enciclopédia saraiva do direito. São Paulo: Saraiva. v. 62, p.154-174.

FERREIRA, L. C.; VIOLA, E. (Org.). (1996). Incertezas de sustentabilidade na globalização. Campinas: Ed. UNICAMP.

FERRY, L. (2007). Aprender a viver: filosofia para os novos tempos. Tradução de Vera Lucia dos Reis. Rio de Janeiro: Objetiva. 
FIORILlO, C. A. P.; RODRIGUES, M. A. (1997). Manual de direito ambiental e legislação aplicável. São Paulo: Max Limonad.

FORTUNATO NETO, J. (2004). Análise do relatório ambiental preliminar (RAP) como instrumento de avaliação e de suporte para o licenciamento ambiental. Dissertação (Mestrado) - Escola de Engenharia de São Carlos. Universidade de São Paulo, São Carlos, 2004.

FREITAS, V. P. (2005). A Constituição Federal e a efetividade das normas ambientais. 3. ed. rev., atual. e ampl. São Paulo: Revista dos Tribunais.

GALEANO, E. (2005). As Veias abertas da América Latina. Prefácio de Isabel Allende. 45. ed. São Paulo: Paz e Terra.

GARRARD, G. (2006). Ecocrítica. Tradução de Vera Ribeiro. Brasília, DF: Ed. Universidade de Brasília.

GOOGLE EARTH (2007). São Carlos - SP - BRA. Disponível em: <http://earthgoogle.com>. Acesso em: 6 jul. 2007.

GOOGLE MAPS (2007). Cidade Aracy, São Carlos - SP - BRA. Disponível em: <http://www.maps.google.com>. Acesso em: 6 jul. 2007.

GRANZIERA, M. L. M. (2003). Direito de águas. São Paulo: Atlas.

GREVE, M. S. (1996). The Demise of environmentalism in american law. Washington: AEI.

HOLANDA, S. B. (2006). Raízes do Brasil. 26. ed. São Paulo: Companhia das Letras.

IANNI, O. (1996). Globalização e diversidade. In: FERREIRA, L. C.; VIOLA, E. (Org.). Incertezas de sustentabilidade na globalização. Campinas: Ed. UNICAMP, p. 93-95.

KRECH, D.; CRUTCHFIELD, R. S. (1971). Elementos de psicologia. Tradução de Dante Moreira Leite e Miriam L. Moreira Leite. 3. ed. São Paulo: Pioneira.

LEMMI, L. (2007). [sem título]: 11 fotografias.

LOPES, M. M. S. (1960). Curso de direito civil (direito das coisas: princípios gerais, posse, domínio e propriedade imóvel). Rio de Janeiro: Freitas Bastos.

MASLOW, A. H. (1970). Motivation and personality. $2^{\text {nd }}$. ed. New York: Harper \& Row.

MAY, P. H. (Org.). (1995). Economia ecológica: aplicações no Brasil. Rio de Janeiro: Campus.

MEIRELLES, H. L. (1990). Direito municipal brasileiro. 6. ed. atual. Atualizada por Izabel Camargo Lopes Monteiro e Yara Darcy Police Monteiro. São Paulo: Malheiros. 
MONTAÑO, M. (2002). Os recursos hídricos e o zoneamento ambiental: o caso do município de São Carlos (SP). Dissertação (Mestrado) - Escola de Engenharia de São Carlos. Universidade de São Paulo, São Carlos, 2002.

NALINI, J. R. (2001). Ética ambiental. Campinas: Millennium.

OLIVEIRA, I. S. D. (2004). A Contribuição do zoneamento ecológico econômico na avaliação de impacto ambiental: bases e propostas conceituais. Dissertação (Mestrado) Escola de Engenharia de São Carlos. Universidade de São Paulo, São Carlos, 2004.

PÁDUA, J. A. (2004). Um Sopro de destruição: pensamento político e crítica ambiental no Brasil escravagista (1786 - 1888). 2. ed. Rio de Janeiro: Jorge Zahar.

PEDRO, F. G.; LORANDI, R. (2004). Potencial natural de erosão na área periurbana de São Carlos-SP. Revista Brasileira de Cartografia, Rio de Janeiro, v. 56, n. 1, p. 28-33, jul.

PEREIRA, C. M. S. (1994). Condomínio e incorporações. 8.ed. atual. segundo a legislação vigente. Rio de Janeiro: Forense.

PIERRI, N. (2005). História del concepto de desarrollo sustentable. In: FOLADORI, G.; PIERRI, N. (Org.). Sustentabilidad? desacuerdos sobre desarrollo sustentable. México: H. Câmara de Diputados; Universidad de Zacatecas; Miguel Angel Porrua, v. 1. cap. 2. p. 1-35.

PREFEITURA MUNICIPAL DE SÃO CARLOS (2004). Mapa elaborado para a implantação do loteamento Cidade Aracy. Desenhado por: Eduardo de Oliveira e Julio César Pereira dos Santos. Engenheiro responsável: Sérgio Busante Geraldes. São Carlos: Departamento de Obras.

REALE, M. (1972). Filosofia do direito. 6. ed. São Paulo: Saraiva.

REALE, M. (2005). Lições preliminares de direito. 27. ed. São Paulo: Saraiva.

SABATOVSKI, E; FONTOURA, I. P. (Org.). (2000). Constituição Federal: 1988. 7. ed. Curitiba: Juruá.

SÁNCHEZ, L. E. (1995). O Processo de avaliação de impacto ambiental, seus papéis e funções. In: LIMA, A.L.B.R.; TEIXEIRA, H.R.; SÁNCHEZ, L. E. (Org.) A Efetividade da avaliação de impacto ambiental no Estado de São Paulo. São Paulo, Secretaria do Meio Ambiente. p. 13-19.

SÃO PAUlO (Estado). Cartório de Registro de Imóveis e Anexos. (1984). Processo administrativo: Agropecuária e Administração de Bens Cidade Aracy S/C Ltda. São Carlos, Ministério Público do Estado de São Paulo. v. 3.

SÃO PAULO (Estado). (1976a). Lei Estadual no 997, de 31 de maio de 1976. Dispõe sobre o controle da poluição do meio ambiente. Disponível em:

〈http://www.cetesb.sp.gov.br/licenciamentoo/legislacao/estadual/leis/1976_Lei_Est_997.pdf> . Acesso em 20 set. 2007. 
SÃO PAULO (Estado). (1976b). Decreto $\mathbf{n}^{\mathbf{0}} \mathbf{8 4 6 8}$, de 08 de setembro de 1976. Aprova o Regulamento da Lei 997, de 31 de maio de 1976, que dispõe sobre a Prevenção e Controle da Poluição do Meio Ambiente. Disponível em:

<http://www.cetesb.sp.gov.br/Institucional/Dec8468.pdf. $>$. Acesso em 20 set. 2007.

SILVA, J. A. (1997). Direito ambiental constitucional. 2. ed. rev. São Paulo: Malheiros.

SOBRAL, H. R. (2002). Globalização e meio ambiente. In: DOWBOR, L.; IANNI, O.; RESENDE, P. E. A. (Org.). Desafios da globalização. 4. ed. Petrópolis: Vozes.

SOUZA, M. P. (2000). Instrumentos de gestão ambiental: fundamentos e prática. São Carlos: Riani Costa.

TUPIASSU, L. V. C. (2003). O Direito ambiental e seus princípios informativos. Revista de Direito Ambiental, São Paulo, v. 30, p. 155-176, abr./jun.

VIOLA, E. (1996). A Multidimensionalidade da globalização, as novas forças sociais transnacionais e seu impacto na política ambiental do Brasil, 1989-1995. In: FERREIRA, L. C.; VIOLA, E. (Org.). Incertezas de sustentabilidade na globalização. Campinas: Ed. UNICAMP. p. 39-40.

VIOLA E. J.; LEIS, H. R. (1998). O Ambientalismo multissetorial no Brasil para além da Rio-92: o desafio de uma estratégia globalista viável. In: VIOLA, E. J. et al. (1998). Meio ambiente, desenvolvimento e cidadania: desafios para as ciências sociais. 2. ed. São Paulo: Cortez; Florianópolis: Universidade Federal de Santa Catarina, cap. 4, p. 134-160.

ZWEIG, S. (1981). Brasil, país do futuro. Tradução de Odilon Gallotti. Rio de Janeiro: Nova Fronteira. 